\title{
NON-PARAMETRIC ANALYSIS OF TECHNICAL EFFICIENCY: FACTORS AFFECTING EFFICIENCY OF WEST JAVA RICE FARMS
}

\section{František Brázdik}
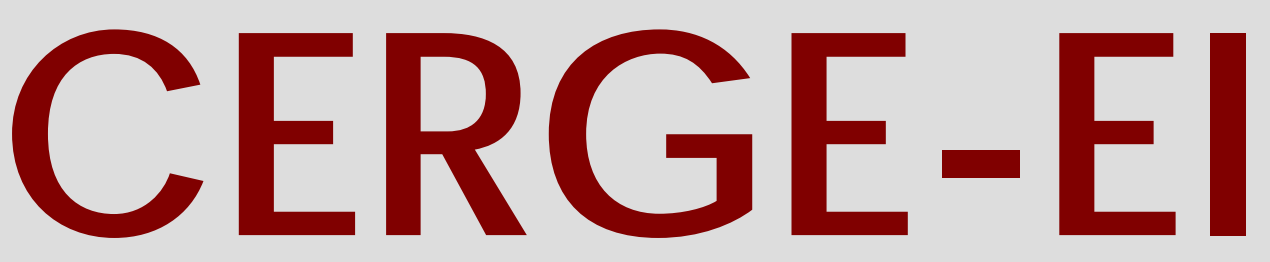

Charles University Centerfor Economic Research and Graduate Education Academy of Sciences of the Czech Republic Ec onomic Institute 


\title{
Working Paper Series $\quad 286$ (ISSN 1211-3298)
}

\section{Non-Parametric Analysis of Technical Efficiency: Factors Affecting Efficiency of West Java Rice Farms}

František Brázdik

\author{
CERGE-EI \\ Prague, January 2006
}


ISBN 80-7343-081-9 (Univerzita Karlova v Praze, CERGE)

ISBN 80-7344-070-9 (Národohospodářský ústav AV ČR, Praha) 


\title{
Non-parametric analysis of technical efficiency: Factors affecting efficiency of West Java rice farms
}

\author{
František Brázdik* \\ CERGE-EI
}

January 2006

\begin{abstract}
The objectives of this analysis are to evaluate the technical and scale efficiency of rice farms in West Java and to identify determinants affecting farms' efficiency. Further, the farm size-productivity relation is investigated. Data Envelopment Analysis is used to estimate technical efficiency scores. Additionally, Tobit regression is used to explain the variation in the efficiency scores related to farm-specific factors. I conclude that farm size is one of the most important factors of farm's technical efficiency and that high land fragmentation was the main source of the technical inefficiency during the final period of the intensification era, known as the Green Revolution.
\end{abstract}

\begin{abstract}
Abstrakt
Ciel'om tejto práce je určenie technickej efektívnosti, výnosov z rozsahu a identifikácia faktorov, ktoré vplývajú na technickú efektívnost ryžových fariem v oblasti Západnej Jávy. Následne, skúmam vztah vel’kosti farmy a jej produktivity. V tejto práci je použitá analýza obalu dát (DEA) na vyhodnotenie technickej efektívnosti fariem. Pomocou odhadu Tobit modelu vysvetlujem variáciu v skóre efektívnosti v závislosti od individuálnych charakteristík fariem. Vel'kost' farmy je významným faktorom vplývajúcim na produktivitu farmy. Záverom tejto práce je tvrdenie, že vztah vel'kosti farmy a jej produktivity nie je monotónne negatívny.
\end{abstract}

Keywords: rice farms, data envelopment analysis

JEL classification: C23, C50, N55, O38, Q11, Q15

${ }^{*}$ Email: frantisek.brazdik@cerge-ei.cz

${ }^{\dagger}$ A joint workplace of the Center for Economic Research and Graduate Education, Charles University, Prague, and the Economics Institute of the Academy of Sciences of the Czech Republic. Address: CERGE-EI, P.O. Box 882, Politických vězňů 7, Prague 1, 111 21, Czech Republic 


\section{Introduction}

The main objective of this study is to investigate the inverse relationship between farm size and efficiency that has became almost a "stylized fact" in the literature on agricultural development. The recent literature focused on agricultural economics in developing countries (e.g., Binswanger, Deininger, and Feder 1995; Barrett 1996; Towsend, Kirsten, and Vink 1998; Helfand and Levine 2004) indicates that the sizeproductivity relation is more complex and caution must be used when advocating policies for agricultural development. This analysis supports the hypothesis that the size-productivity relation is not straightforward negative and for small farms (less than 5 hectares) there exists a threshold size over which efficiency growth is observed with increasing farm size.

Recently, the Data Envelopment Analysis (DEA) studies (Dhungana, Nuthall, and Nartea 2004; Sang and Hyunok 2004; Krasachat 2004; Umetsu, Lekprichkui, and Chakravorty 2003; and Wadud and White 2000), with focus on the evaluation of rice farms' efficiency, are motivated by the importance of rice production in the economies of Asian countries. In this study, I focus on Indonesian rice production in the West Java area. West Java province is the home of intensification programs and agricultural development institutions in Indonesia and the research interest in this area is emphasized by the fact that farmers from Java island produced over $60 \%$ of Indonesia's total rice output at the time of the survey. Therefore, the aim of this paper is to evaluate the technical efficiency of rice farms. To do this, the DEA approach is employed to compute the technical and scale efficiency of farms.

Subsequent analysis of technical and scale efficiency is followed by the analysis of farm characteristics and efficiency score relations. To evaluate these relations, a panel data version of the Tobit model is used. The evaluation of the effect of the farm specific factors on the efficiency scores is focused on the farm size-productivity relation. Also, the effect of the later stage of the Indonesian government's intensi- 
fication program (known as BIMAS) on technical efficiency impact is investigated.

Further, analysis presented in this paper illustrates how to test hypotheses related to the DEA performance measures using the data set that was the focus of recent studies (Horrace and Schmidt 1996; Druska and Horrace 2004; Brázdik 2005) on methodological issues related to production frontier estimation. Horrace and Schmidt (1996) compare various stochastic frontier methods (SF) with regard to constructed confidence intervals for performance score estimates, and they prefer to use the SF methods for testing hypotheses related to performance scores because the DEA does not provide confidence intervals for performance measures. However, Simar and Wilson (2000) show how a simple underlying model of the data generating process defines a statistical model, allowing determination of the statistical properties of the nonparametric estimators in the multi-output and multi-input case.

This paper is organized as follows. The next section reviews the history of the intensification program aims and rice production technology during the "Green Revolution" period. The third section gives a review of the DEA methodology used to evaluate farms' efficiency scores and of the Tobit estimation technique used to estimate the effects of characteristics on the efficiency score. The fourth section presents results from the calculation of technical efficiency measures and estimation of its determinants. The last section summarizes the results of this study and their relations to intensification policies.

\section{Rice farming in Indonesia}

The following review is focused on the main objectives of the BIMAS intensification program. Also, in this section factors related to the technical inefficiency of rice farming are discussed. In the data subsection, a description of the analyzed data is given. 
While in the 1960s agriculture contributed $51 \%$ to Indonesian GDP and, according to Pearson et al. (1991), despite output growth of agricultural productivity the contribution to GDP decreased to $31 \%$ by the end of the 1970s and further to $25 \%$ by the end the 1980s. Even though there was a decline in the contribution to GDP, the importance of rice for the economy is stressed by the fact that it contributes $50 \%$ of Indonesian agriculture production because rice is a staple food. Also, in rice growing areas it is a major source of income for farmers. Therefore, a critical part of the economic stabilization process is stable and low rice prices that became the goals of agriculture intensification programs.

To stabilize rice prices and increase output of domestic rice producers, the Indonesian government heavily supported the rice farming sector by subsidizing inputs for agricultural production, and consumer prices of rice were held below world market prices (Erwidodo, Sudaryanto, and Bahri 1999). Pearson et al. (1991) illustrate this situation by the fact that in the 1970s, the Indonesian rice price averaged $30 \%$ below the world market price. Due to the costs of subsidization and the importance of rice as a food supply as well as the threat of famine, the Indonesian government claimed self-sufficiency as a national objective.

To meet this long term objective, the Indonesian government has been allocating a sizable amount of its budget to the agricultural sector since the beginning of the 1970s. These funds has been used to introduce various intensification programs (e.g., BIMAS, INMAS and IPM) within the last thirty years. The effects of these programs were following typical patterns for the introduction of new technology. The early and late stages showed just a little productivity growth while the most rapid growth is observed in the middle period. This is due to gradual implementation of new methods in the early stages and then due to the fact that the productivity limits of the new technology were reached in the later period (e.g., Umetsu, Lekprichkui, and Chakravorty 2003). 
Indonesia used to import $25 \%$ of all rice traded in the world market in the $1960 \mathrm{~s}$ and early 1970s, but exported small amounts in the late 1980s. This change, known as the "Green Revolution" is a result of adopting new rice production techniques, modern rice varieties and organizational changes that were introduced as a result of intensification programs. According to Lokollo's (2002) report, in the mid 1980s Indonesia changed its position from a net rice importer to being self-sufficient. Despite this production growth and increase in rice production, the population growth pressure reverted the self-sufficiency trend and in the late 1980s Indonesian production was again not sufficient to meet domestic demand for rice and Indonesia returned to a net importer position.

The first efforts of the Indonesian government to improve rice production technology are dated to the 1950s. These efforts included development of irrigation systems, establishment of "paddy centers" and soil conservation. The growth of rice production until the late 1960s was driven through enlargement of rice production areas by conversion from sugar-growing land while the rice yield stagnated at 2 tons per hectare.

Often by use of force, the new high-yielding rice varieties (HYV), fertilizers and pesticides were introduced into the production process in the beginning of the intensification programs. Also, credit programs for farmers forced them to purchase input packages, and they had to take the prescribed package of seeds, fertilizers and pesticides. Inputs for rice production were distributed through the village administration. The village administration forced farmers (by cutting down the crops of those who were not growing rice with the assistance of the army) to plant rice instead of growing more profitable crops. Moreover, this administration often decided to spray large areas with pesticides using planes.

As Lokollo (2002) or Daryanto, Battese, and Fleming (2002) review, more farmer friendly intensification programs were introduced later, e.g., BIMAS (seeds 
and fertilizer, technical know-how, credit and guaranteed markets) and INMAS (extension of BIMAS, subsidized fertilizes and pesticides). In the late 1970s, extensions of the BIMAS program in the form of the INSUS (in irrigated areas) and OPSUS (inputs for farms for free according local resource endowment) programs for groups of farmers were introduced. These programs focused on the management of farms and planning. To promote coordination of farmers and to capture economies of scale, another extension of the BIMAS program was introduced in the form of the SUPRA INSUS program in the late 1980s.

In the 1990s Indonesia suffered from a deep political, economic and financial crisis. As Erwidodo, Sudaryanto, and Bahri (1999) review, the Indonesian government was also forced to reform its agricultural policies. This led to agricultural liberalization because the regulatory body (National Logistic Agency, BULOG) was seen as the main source of agricultural distortions. Liberalization included elimination of the state monopoly on agricultural imports, introduction of international and provincial tariffs and the reduction of trade restrictions on a number of agricultural products. In 1998, the fertilizer distribution monopoly was eliminated and fertilizers are traded at market prices. Further reforms include promotion of adequate incentives to rice farmers, changes in the role of government in marketing and food distribution and further reduction of non-tariff barriers for agricultural markets.

Recently, the main objective has not been to become self-sufficient in rice production but to adequately feed the population and reduce poverty. This goal should be achieved by reducing distortions in the farming input market that result from heavy subsidization of fertilizers and pesticides. These reforms should be followed by an increase in competition in the agricultural sector, which should promote more efficient use of production factors. Erwidodo, Sudaryanto, and Bahri (1999) conclude that despite the unclear results of the introduced agricultural reforms in 
the near-term, there remains a potential source of future economic growth.

As it follows from the above intensification program review, the BIMAS program (Bimbingan Masai or "mass guidance" intensification program) was the most important ingredient of the rice development policy in the 1970s and its influence on productivity increase declined in the 1980s after most farmers adopted HYVs and were capable of funding the production inputs from rice farming profits. According to Pearson et al. (1991), in 1969 the yield on sawah in Java was on average 2.6 tons of rice per hectare, and until 1987 these yields had increased to about 5 tons per hectare.

The most significant factor of this increase in rice productivity in the 1970s and 1980s was the spread of high-yield rice varieties. By the mid-1980s, $85 \%$ of rice farmers used high yield variety seeds, compared with $50 \%$ in 1975 . This was a result of the promotion of HYVs together with subsidized fertilizers, pesticides, and credit through the "mass guidance" intensification program. During the 1970s, Indonesian farmers increased their consumption of pesticides sevenfold and their consumption of fertilizers fourfold, even though Indonesian farmers used only 20$25 \%$ of the amounts used by farmers in Japan, Taiwan or South Korea; see Table 6.6 in Barker, Herdt, and Rose (1985). The later introduced extensions of the BIMAS program continued to offer technical assistance to farmers unfamiliar with new cultivation techniques.

The general belief of farmers involved in the BIMAS program was that more agrochemical inputs (fertilizers and pesticides) will lead to even higher yields. Gallagher explains that the massive use of subsidized pesticides (farmers paid only 10 to $20 \%$ of the world price of pesticides) led to outbreaks in rice production when more than one million of hectares were infested by pests, e.g., insects like brown planthopper. The applied pesticides damaged the rice ecosystems so much that beneficial predators and parasites were destroyed; therefore, migrating pests sur- 
vived without any mortality and destroyed crops. To help reduce pesticide use, in 1989, the subsidy on pesticides was eliminated. Gallagher concludes that since 1989, no outbreaks have occurred and farmers were able to increase yields without increased pesticide use.

The aforementioned problem of heavy pesticide use is only one from a range of socio-economic and demographic factors that determine the efficiency of rice farms. Literature on the technical efficiency of rice farms (Wadud and White 2000; Daryanto, Battese, and Fleming 2002) lists factors like credit availability, farm size, weather, topography and poor soil as the principal production constraints. Technical factors include irrigation (often not functional in the dry season when the irrigation system is in short supply of water), plot size and land degradation. Especially during the wet season, the quality of roads and communication facilities constrain the movement of inputs to the paddies, which results in crop losses. Also non-physical factors like experience, age, years of schooling, ownership structure and information availability are considered as relevant, e.g., Parikh, Ali, and Shah (1995); Dhungana, Nuthall, and Nartea (2004); Timmer (1971); and Dhungana, Nuthall, and Nartea (2004).

\subsection{Data description}

The data used in this study were previously used by Druska and Horrace (2004) and Horrace and Schmidt (1996) in their studies on theoretical developments of methods for stochastic frontier analysis (SFA). In Brázdik (2005), the sensitivity of efficiency scores with respect to choice of frontier estimation (SFA, DEA and stochastic DEA) approach was examined.

This panel data come from an individual rice farm survey by the Indonesian Ministry of Agriculture that began in 1977. These farms were selected from six villages (Wargabinangun, Lanjan, Gunungwangi, Malausma, Sukaambit, Ciwangi) 
in the Cinamuk River Basin area in West Java, and farms were surveyed over six growing periods (three wet and three dry periods). These villages are a sample of heterogenous environment with various altitudes (sea level, central area of West Java and highland) and village infrastructure (both in low and highlands, where not all villages are accessible by all-weather local roads).

The sample used for analysis covers 160 farms after I removed outliers (performance outliers and errors in data) according to a yield per hectare criterion and comparison of net and gross yields of farms. After this correction, the used data still contains farms with a wide range of characteristics.

Table 1 summarizes the descriptive statistics of used inputs and outputs. Land is considered as the most important input, and it is represented as the size of rice farms in hectares. Approximately $90 \%$ of farms in the sample are smaller than 2 hectares. As reported by Fredierick and Worden (1992) and Pakpahan (1992), the 1973 and 1983 agricultural census showed that about $44 \%$ percent of all farm households were either landless or operated holdings too small (0.5 hectare) to meet more than subsistence requirements. The census shows that average farm size in Java was 0.66 hectare, while in other parts of the archipelago and outer islands the farms were larger and the average size ranged from about 1.33 to 2.71 hectares. At the same time, the average size of rice farms in Thailand was 2.9 hectares and 8.7 hectares in the USA. Ray (1998) summarizes that the low value of per capita land holdings is transformed into the fact that a significant fraction of farms are owneroperated. The other contractual arrangement of land renting in Asia that occurs frequently is sharecropping, under which tenants cede to the landlord a prescribed fraction of his crop. Ray (1998) reports that $60 \%$ of tenanted land in Indonesia is tenanted under the sharecropping arrangement. In the analyzed sample, one third of farmers operate at least a part of their land under share tenancy.

Based on previous research on rice farms in Asia (e.g., Erwidodo 1990, Umetsu, 
Lekprichkui, and Chakravorty 2003 and Krasachat 2004), I use quantity of seeds, urea, triple superphosphate (TSP) and labor to quantify the rest of the inputs that characterize production technology. I abstract from the role of mechanization or use of animals as production inputs because from Barker, Herdt, and Rose's (1985) review of mechanization studies, it follows that almost no change occurred in cropping intensity after the introduction of tractors for land preparation. Moreover, they report a field experiment which compared alternative land preparation techniques and failed to show any difference in wetland rice yields.

In the sample, the employment of HYVs is still very low but tends to increase over the observed periods. Close to one third of the farmers used HYVs in the first observed season, and the use of HYVs increased to $50 \%$ in the last period. According to statistics presented by Lokollo (2002), this reflects the overall process of HYV employment, when in $197433 \%$ of farmers employed modern rice varieties and employment was increased to $77 \%$ of farmers by 1989 . The use of the HYVs is one of the rice production growth drivers, when HYVs yielded on average approximately 1.4 times more rice than traditional varieties in the 1970s in Asia.

Total quantity of urea and phosphate are used to measure the amount of fertilizers applied by farmers because the use of fertilizer make a substantial contribution to the rice yield increase. But as Barker, Herdt, and Rose's (1985) estimations of yield response to amount of fertilizer show, this contribution decreases with an increase in the level of applied fertilizer.

Labor includes both family and hired labor in rice production and is measured by man-hours. Labor is used to repair dikes; raise, pull and transplant seedlings; harvest and thresh. Rice production in Indonesia is characterized by its very high labor intensity and very low level of mechanization; in this area there was only 1 tractor available per 200 hectares. Therefore, land preparation in the wetland cultivation area on Java remains largely unmechanized during the considered period 
and Pearson et al.'s (1991) estimate based on calculations from survey data place tractor use on about $7 \%$ of total cultivated area in 1987. Barker, Herdt, and Rose (1985) report that in the 1970s innovative farmers on Java used 200-250 days of labor to cultivate 1 hectare of rice. On average, Indonesian farmers in the analyzed sample used 173 man-days per hectare, but this is still three times more than reported for Thailand and Burma (Table 3.5 in Barker, Herdt, and Rose 1985) and approximately two times more than Umetsu, Lekprichkui, and Chakravorty (2003) report for the Philippines. Due to the low employment of mechanization, the considered production mix does not include tractor or animal work.

In this study, two definitions of a farm's outputs are used to assess the robustness of the results with respect to production mix specification. In the model, referred to as one-output, a farm's output is described only by the gross observed rice production in kilograms. Due to the high labor intensity of rice harvesting, farmers usually hire sharecroppers to harvest rice. The harvesting cost is paid in terms of rough rice harvested. Therefore, the gross rice production can be decomposed into net yield and rice used to cover the harvest costs measured in kilograms of rice and this model is referred to as the two-output model.

In the second stage of analysis, the effect of the type of rice variety together with land status (owner, sharecropper) and type of the BIMAS program participation (non-BIMAS farmer, mixed, BIMAS farmer) is examined. In the analyzed sample, farmers tend to drop out from the program. In the first period $66 \%$ of farmers are not taking part in the program while in the last period $87 \%$ are not. Further, I also investigate the influence of the price (in Rupiah per kilogram) of seeds, urea and phosphate on the technical efficiency scores because due to low prices, farmers tend to overuse cheap inputs. Overuse of inputs may lead to a decrease in productivity rather than to an increase as in the case of pesticide use. In this analysis, the use of chemical protection of plants is measured by pesticide costs (in thousands of 
Rupiah). ${ }^{1}$

\section{Methodology}

In this work, a two-stage procedure is employed to evaluate the effects of rice farm characteristics on the efficiency of production mixes used by farms. In the first stage, the performance of the decision making unit (DMU, farm) is calculated by the non-parametric approach based on Farrell's (1957) measures of efficiency by Farrell (1957) and Farrell and Fieldhouse (1962). This approach to the measurement of technical efficiency is one of the most popular approaches in recent performance analysis studies.

In Farrell's (1957) concept, the overall efficiency (OE) is a multiplicative combination of technical (TE) and allocative efficiency $(\mathrm{AE})$, so that $\mathrm{OE}=\mathrm{TE}^{*} \mathrm{AE}$. Allocative efficiency measures the extent to which an analyzed DMU produces its outputs in a proportion that minimizes costs of production, assuming that the unit is already fully technically efficient. Technical efficiency measures the extent to which inputs are converted to outputs relative to the best practice and does not depend on prices of inputs and outputs as does Hanoch and Rothschild's (1972) non-parametric concept for testing hypotheses about production relations.

In Farrell's (1957) concept, the farmer's decision process may fail in two different ways. Economic theories usually consider the case when the marginal product of some or all factors are not equal to their marginal costs, then the allocative decision is inefficient. The second case considers the failure to produce the maximum possible output from a given mix of inputs and this means that the technical decision is inefficient. In this work, technical efficiency serves as a proxy for overall efficiency because in the environment with input and output prices heavily distorted by various subsidization schemes, allocative efficiency does not work as a

\footnotetext{
${ }^{1}$ In the late 1970s, 1000 Indonesian Rupiah had a value of approximately 2 USD.
} 
good measure of efficiency.

In the first stage of the analysis, the technical efficiency of individual farms is evaluated by the data envelopment approach (DEA). Since the production frontier in the DEA approach is deterministic, the resulting efficiencies contain noise from data. Therefore, in the second stage of this analysis, the features of the operating environment (farm characteristics) are used to explain the computed technical efficiency scores by estimating an efficiency model. As it follows from the DEA efficiency score definition, the DEA score falls between the 0 and 1 , making the dependent variable (efficiency score from the first stage of analysis) a limited dependent variable. Therefore, the Tobit model is suggested (e.g., Cooper 1999; Grigorian and Manole 2002) as an appropriate model in the second stage of analysis when considering the effects of a farm's characteristics on the farm's efficiency score.

\subsection{Efficiency measurement}

The DEA approach introduced in a seminal paper by Charnes, Cooper, and Rhodes (1978) uses linear programming to pursue Farrell's (1957) concept of technical efficiency to evaluate performance. Charnes, Cooper, and Rhodes's (1978) approach deals with multiple inputs and multiple output technology by computing the maximal performance score for each decision making unit relative to all other units in the sample. For each unit, the unit's performance score is calculated by comparing its production mix with an efficient unit (located on the technology frontier) or with a convex combination of different efficient units (weighted mix of other decision making units).

The common feature of estimation techniques based on Farrell's (1957) efficiency definition is that the information is extracted from extreme observations in the sense of technical efficiency, to form the best practice production frontier. This makes 
DEA scores sensitive to errors in data. However, the main advantage of the DEA approach is that it does not require the assumption of a functional form for the specification of the input-output relation.

Technical efficiency is considered in terms of the optimal combination of inputs to achieve a given level of output (an input-orientation) or the optimal output that can be produced given a set of inputs (an output-orientation). This analysis is focused on input-oriented models, where the DMU's ability to consume the minimum input given the level of outputs that should be attained is considered. The input orientation is more appropriate in this case because the output level is given by the target of rice production, which should reach the self-sufficient level (zero imports). The decision on the orientation of DEA models is also supported by considering the degree of a farmer's control over variables in the DMU's production mix (rice farm). Rice farmers have more control over their inputs than their outputs. Therefore, as in other agricultural productivity studies (e.g., Wadud and White 2000; Davidova and Latruffe 2003; and Krasachat 2004), the input-oriented DEA model is used in this study.

When using the DEA approach, the set of $n$ homogenous farms described by an input vector $x_{j}=\left(x_{1 j}, \ldots, x_{m j}\right)^{T} \in \mathbb{R}_{+}^{m}$ of $m$ inputs are employed to produce $s$ outputs in amounts described by vector $y_{j}=\left(y_{1 j}, \ldots, y_{s j}\right)^{T} \in \mathbb{R}_{+}^{s} \cdot{ }^{2}$ Therefore, data on production process observations consist of $n$ pairs of input-output vectors $\left(x_{j}, y_{j}\right) \in \mathbb{R}_{+}^{m+s}$ and by aggregating these vectors, the following matrix notation is used to describe inputs $X_{m \times n}=\left(x_{1}, \ldots, x_{n}\right)$ and outputs by matrix $Y_{s \times n}=$ $\left(y_{1}, \ldots, y_{n}\right)$.

The DEA methodology approach developed by Charnes, Cooper, and Rhodes (1978) and reviewed by Seiford and Thrall (1990) and by Charnes et al. (1994) shows that Farrell's (1957) input-oriented efficiency measure for the $\mathrm{DMU}_{j}$ is found

\footnotetext{
${ }^{2}$ Here, $\mathbb{R}_{+}$means the set of positive real numbers and $\mathbf{1}$ is a column vector of ones.
} 
as an optimal solution to the following linear programming problem (model):

$$
\begin{aligned}
\min _{\lambda_{j}, \theta_{j}, e_{j}, s_{j}} & \theta_{j} \\
\text { s.t. } & X \lambda_{j}+e_{j}=\theta_{j} x_{j}, \\
y_{j}-Y \lambda_{j}+s_{j} & =0, \\
\varphi\left(\mathbf{1}^{T} \lambda_{j}\right) & =\varphi, \\
\lambda_{j}, e_{j}, s_{j} & \geq 0,
\end{aligned}
$$

where $\lambda_{j} \in \mathbb{R}_{+}^{n} ; \theta_{j} \in \mathbb{R}_{+} ; e_{j} \in \mathbb{R}_{+}^{m} ; s_{j} \in \mathbb{R}_{+}^{s}$ and $\varphi$ is 0 for the model (CCR model) with constant returns to scale introduced by Charnes, Cooper, and Rhodes (1978) and 1 for the model (BCC model) with variable returns to scale by Banker, Charnes, and Cooper (1984). For the $\mathrm{DMU}_{j}$ the optimal value $\theta_{j}^{*}$ measures the maximal equi-proportional input reduction without altering the level of outputs. The vector $\lambda_{j}^{*}$ of intensity variables indicates participation of each considered farm in the construction of the virtual reference farm that the $\mathrm{DMU}_{j}$ is compared with.

Problem 1 is solved $n$ times to generate the optimal values of the objective function and the elements of intensity variables vector $\lambda$ for each farm. ${ }^{3}$ In the DEA literature (e.g., Charnes et al. 1994; Banker, Charnes, and Cooper 1984), the efficiency of the $\mathrm{DMU}_{j}$ is evaluated using the optimal solution $\left(\lambda_{j}^{*}, \theta_{j}^{*}, e_{j}^{*}, s_{j}^{*}\right)$ of Problem 1 under the assumption of the selected returns to scale (RTS) type according to the following theorem:

Theorem 1. Efficient $D M U_{j}$ : The $D M U_{j}$ is DEA efficient if both of the following conditions are satisfied: 1) $\theta_{j}^{*}=1$; and 2) all values of slacks are zero: $\mathbf{1}^{T} e_{j}^{*}=0$ and $\mathbf{1}^{T} s_{j}^{*}=0$. Otherwise, the $D M U_{j}$ is inefficient.

If the $\mathrm{DMU}_{j}$ is identified as inefficient according to Theorem 1, optimal values

\footnotetext{
${ }^{3}$ For more information on solving DEA models, see chapter "Computational aspects of DEA approach" in Charnes et al. (1994).
} 
of non-proportional slacks $e_{j}^{*}, s_{j}^{*}$ and the optimal value $\theta_{j}^{*}$ identify the sources and levels of present inefficiency and the following input-oriented efficiency measure by Tone (1993) that accounts for the presence of proportional and non-proportional slacks:

$$
\chi_{j}=\left(\theta_{j}^{*}-\frac{\mathbf{1}^{T} e_{j}^{*}}{\mathbf{1}^{T} x_{j}}\right) \frac{\mathbf{1}^{T} y_{j}}{\mathbf{1}^{T} Y \lambda_{j}^{*}}
$$

Properties of Tone's (1993) efficiency measure guarantee that this efficiency measure uniquely identifies the efficient $\mathrm{DMU}_{j}$ when $\chi_{j}=1$. Further, the properties of $\chi_{j}$ (monotonically increasing in values of inputs and outputs; decreasing in the relative values of the slacks; and units' invariancy) provide rationale for the use of this efficiency measure to create efficiency ranking for the analyzed DMUs.

Solving the CCR version of the problem $1(\varphi=0)$, the total technical efficiency measure $\phi_{j}^{*}(C C R)$ is obtained by comparing small scale units with large scale units and vice versa without considering the economies of scale. This may be inappropriate for all of the farms in the sample; therefore, the BCC model ( $\varphi=1$ in problem 1) that allows for variations in the RTS is considered. The BCC model formulation allows one to calculate the pure technical efficiency $\phi_{j}^{*}(B C C)$ and decompose the technical efficiency score into pure technical efficiency and scale efficiency (SE). Evaluation of the scale efficiency measure of the $\mathrm{DMU}_{j}$ assumes calculation of $\phi_{j}^{*}(B C C)$ and $\phi_{j}^{*}(C C R)$ and the scale efficiency measure is calculated as in the summary of SE calculation methods by Löthgren and Tambour (1996):

$$
S E_{j}=\frac{\phi_{j}^{*}(C C R)}{\phi_{j}^{*}(B C C)} .
$$

The value of the $\mathrm{SE}$ measure is interpreted in the following way: if $S E_{j}=1$, then the $\mathrm{DMU}_{j}$ is considered as a scale efficient unit and this unit shows the constant returns to scale property $(\mathrm{CRS})$; if $S E_{j}<1$, then the production mix of the $\mathrm{DMU}_{j}$ 
is not scale efficient.

Scale inefficiencies arise because of the presence of either decreasing (DRS) or increasing (IRS) returns to scale. As largely outlined in the DEA literature (e.g. Färe and Grosskopf 1994; Zhu and Shen 1995; and Löthgren and Tambour 1996), returns to scale characterize locally the production frontier so that they can be solely computed with respect to originally efficient DMUs or projections (equi-proportional input reduction) of inefficient DMUs belonging to the production possibility set.

Following Löthgren and Tambour's (1996) review of identification of the RTS type procedures, the method of the sum of the intensity variables is employed. This method originates from Banker, Charnes, and Cooper's (1984) analysis of the CCR model by Charnes, Cooper, and Rhodes (1978). The ability to determine the RTS type of the DMU by Banker, Charnes, and Cooper's (1984) method was later questioned by Färe and Grosskopf (1994) and an improved method of sum of the intensity variables is given, as in Zhu and Shen (1995), by the following theorem:

Theorem 2. Sum of intensity variables method: For the specific $D M U_{j}$, let us define $S E_{j}=\frac{\theta_{j}^{*}(C R S)}{\theta_{j}^{*}(V R S)}$. We have $S E_{j}=1$ iff the $D M U_{j}$ exhibits CRS; otherwise if $S E_{j}<1$, then $\sum \lambda_{j}^{*}<1$ iff the $D M U_{j}$ exhibits IRS; $\sum \lambda_{j}^{*}>1$ iff the $D M U_{j}$ exhibits $D R S$.

An important part of the DEA is the analysis of efficiency score sensitivity with respect to model specifications. In this paper, the comparison of the stochastic frontier method with the DEA and the stochastic DEA approach presented in Brázdik (2005) is utilized. For analysis of efficiency determinants, the additive formulation of the production function is used because as shown in Brázdik (2005) this formulation (piecewise linear envelopment surface) is more consistent (in terms of rank correlation) with stochastic frontier analysis than the model with multiplicative formulation (piecewise Cobb-Douglas envelopment surface). Further, the robust- 
ness of calculated efficiency rankings is analyzed with respect to model specification by use of two different output specifications. The consistency of efficiency ranking is evaluated by using a rank correlation coefficient by Spearman (1904) and the hypothesis of rank independence is tested. Spearman's (1904) rank correlation coefficient is used because its important feature is lower sensitivity to extreme values when compared with the standard correlation coefficient. ${ }^{4}$

\subsection{Tobit model}

The goal of the second stage is to explore relationships between the technical efficiency measure and other relevant variables such as size, rice variety used, BIMAS participation and intensity of factor employment. Some of the considered factors are neither inputs nor outputs of the production process, but rather circumstances faced by decision makers, e.g., wet growing period, prices of inputs or location of paddy.

The used two-stage procedure originates from Timmer's (1971) idea for the explanation of aggregated (at state level) technical efficiency of individual farmers. Kumar and Russell (2002) used this procedure to regress the change in efficiency against the output per worker to show that output per worker is positively related with the change in the technology index constructed by using the DEA. Further, Cooper (1999) argues that the second stage regression is useful for checking the consistency of the DEA results and identification of explanatory variables. Moreover, as Fried, Schmidt, and Yaisawarng (1999) summarize, an advantage of the two-stage approach is that the influence of the external variables on the production process can be tested in terms of both sign and significance. However, they point out that the disadvantage is that the second stage regression ignores the information contained in the slacks and surpluses and this may bias the parameter

\footnotetext{
${ }^{4}$ For implementation details of Spearman's (1904) rank correlation coefficient, see Stata Corporation (2003).
} 
estimates and give misleading conclusions regarding the impact of each external variable on efficiency. Therefore, they proposed a four-stage process to correct the measure of technical efficiency for the presence of slacks. Fried et al. (2002) present an improved version of Fried, Schmidt, and Yaisawarng's (1999) technique for incorporating environmental effects and statistical noise into a producer performance evaluation based on data envelopment analysis (DEA) where the slacks are decomposed to a part attributable to environmental effects, a part attributable to managerial inefficiency and to a part attributable to statistical noise.

Let us assume that the efficiency of farms could be presented in a simplified setting suggested by many studies (e.g., Parikh, Ali, and Shah 1995; Hallam and Machado 1996; Llewelyn and Williams 1996; Shafiq and Rehman 2000; and Grigorian and Manole 2002) by the following function:

$$
\chi_{j t}=E\left(F_{j t}, P_{j t}, X_{t}, \epsilon_{j t}\right)
$$

where $\chi_{j t}$ is the measure of farm $j$ efficiency in period $t, F_{j t}$ is a vector of farm $j$ specific variables, $P_{j t}$ is a vector of economic factors, $X_{t}$ is a vector of period $t$ external factors that are likely to affect the efficiency of farm $j ; \beta_{j}$ is a vector of parameters to be estimated and $\epsilon_{j}$ is the part attributable to statistical noise.

The DEA approach provides efficiency measure $\chi_{j t}$ with distribution bounded between 1 and 0 . Alternatively, the efficiency scores are censored at 0.9 when assuming that there is not too much difference between fully efficient farms and over $90 \%$ efficient farms. In this case the ordinary least squares method can not be applied because the expected errors will not equal zero, and so standard regression will provide a biased estimate. Therefore, the limited dependent variable approach is preferred and the Tobit model is applied.

Following Kmenta (1990) and Wooldridge (2002), the model can be written in 
following way:

$$
\chi_{j t}^{*}=\alpha^{T} F+\beta^{T} P+\gamma^{T} X+\varepsilon_{j t},
$$

where $\chi_{j t}^{*}$ is a latent variable that refers to the technical efficiency of rice farms and $x$ are explanatory variables. However, due to nature of the efficiency measure, the following is observed:

$$
\begin{array}{ll}
\chi_{j t}=0 & \text { if } \quad \chi_{j t} \leq 0 \\
\chi_{j t}=\chi_{j t}^{*} & \text { if } \quad 0<\chi_{j t}<1 \\
\chi_{j t}=1 & \text { if } \quad 1 \leq \chi_{j t} .
\end{array}
$$

To estimate the effects of farm characteristics on the technical efficiency score, the Tobit and random-effect Tobit models are used. The random-effect Tobit model captures individual-specific effects, assuming no correlation between the individualspecific effects and explanatory variables. The random-effect Tobit model for efficiency scores is considered in the following form:

$$
\chi_{j t}^{*}=\alpha^{T} F+\beta^{T} P+\gamma^{T} X+\nu_{j}+\epsilon_{j t}
$$

assuming that $\chi_{j t}$ is censored at 0 and 1 (0.9 respectively). In this formulation, random-effects $\nu_{j}$ are iid $N\left(0, \sigma_{\nu}^{2}\right)$ and $\epsilon_{j t}$ are iid $N\left(0, \sigma_{\epsilon}^{2}\right)$ independently of $\nu_{j}$. Assessed models are estimated using the maximum likelihood estimation procedures implemented in STATA.

In the following analysis, the fixed-effect Tobit model is not used to model the efficiency score, as there does not exist a sufficient statistic that allows the fixed-effect to be conditioned out of the likelihood. Unconditional fixed-effect Tobit models may be fitted by using the Tobit model with an individual indicator. 
However, these estimates are biased. According to Greene (2004), the variance estimator (crucial parameter for inference and analysis purposes) in the Tobit model is affected specially in samples with a small number of time periods observed, as in the case of this analysis.

However, it is possible to control for correlation with unobserved heterogeneity because Wooldridge (2002) suggests that in this case one should utilize an assumption presented by Mundlak (1978). Mundlak (1978) assumed that unobserved heterogeneity can be modelled as a function of the means of included regressors. So, the following relation is assumed: $\nu_{j}=\bar{\alpha}^{T} \bar{F}_{j}+\bar{\beta}^{T} \bar{P}_{j}+\bar{\gamma}^{T} \bar{X}_{j}+\delta_{j}$. Here, $\delta_{j}$ is assumed to be a part of a farm's unobserved heterogeneity such that it is uncorrelated with regressors $F, P, X$ and $\bar{F}_{j}, \bar{P}_{j}, \bar{X}_{j}$, where $\bar{F}_{j}, \bar{P}_{j}, \bar{X}_{j}$, are vectors of farm $j$ means for individual regressors over the observed growing periods. After, the additional set of mean regressors is included, the efficiency equation can be estimated by the random-effect Tobit approach.

\section{Results}

\subsection{Technical efficiency}

As mentioned in previous sections, the technical efficiency and pure technical efficiency scores are evaluated by use of the input-oriented DEA models via solving Problem 1 for two different output specifications under the assumption of a period specific production frontier. The model with the output specified by gross rice production is referred to as the one-output model and the model with harvest cost and net rice used to specify production output is referred to as the two-outputs model. Further, for the two-outputs specification, efficiency scores were calculated under the assumption of the time invariant production frontier (pooled sample, referred to as the pooled DEA). 
The DEA estimates of technical efficiency are summarized in Table 2. The differences in efficiency score $(\chi)$ and technical efficiency score $(\theta)$ result from the presence of positive non-proportional slacks $(e, s)$. From comparison of $\chi$ and $\theta$ values, it can be observed that these non-proportional slacks are less important than equi-proportional reduction of inputs $(\theta)$.

From comparison of the reported technical efficiency scores with Krasachat's (2004) results for Thai rice farms, it can be concluded that West Javan and Thai rice farms are operating approximately at the same level of relative efficiency. Krasachat (2004) reports an average technical efficiency score of 0.74 for Thai farms while in the analyzed sample of West Javan farms, the technical efficiency ranges from 0.60 to 0.77 (under the assumption of the time varying production possibility frontier). Also, the technical efficiency scores of West Javan rice farms are lower than the technical efficiency scores of rice farms in Bangladesh reported by Wadud and White (2000), where the average technical efficiency ranges from 0.86 to 0.91 and standard deviation ranges from 0.10 to 0.12 .

With awareness of the fact that Llewelyn and Williams (1996) used an outputoriented measure, these results can be liken to results presented in Llewelyn and Williams's (1996) study on multi-product food-crop producing farms $(58.1 \%$ of their production can be attributed to rice) in East Java during the 1994 growing season. Llewelyn and Williams (1996) reports farms' technical efficiency in the range from 0.95 to 0.98 with standard deviation ranging from 0.019 to 0.043 . Also, the histograms of computed technical efficiency scores plotted in Figure 1 and 2 illustrate the observed high degree of diversity in farms' performance. In both figures, the typical pattern of the DEA efficiency measures characterized by a peak at one is observed. From a comparison of standard deviation values, it follows that productivity performance of West Java rice farms was much more heterogenous than in other countries at that time and in East Java in the early 1990s. Therefore, 
it is appropriate to conjecture that the low average technical efficiency performance of West Java farms is caused by high heterogeneity of rice farming practices in Indonesia in the late 1970s.

Assessing the scale efficiency results reported in Table 2, one can conclude that scale inefficiency is not the major source of Indonesian rice farm inefficiency. The average scale efficiency value of 0.90 is comparable to scale efficiency scores of farms in Thailand (0.96 reported by Krasachat 2004) and Bangladesh (0.91 reported by Wadud and White 2000). The international comparison of the RTS identification is presented Table 3. These results shows that most of the farms in West Java and Bangladesh operate in the production possibility region with a decreasing returns to scale property. While in the case of Thailand and East Java, most of the farms are operating in either the constant or increasing returns to scale region of their production possibility set.

From these results it follows that increases in input intensity leads to less than proportional increases in outputs because farmers were not using the proper mix of inputs that could generate constant or increasing returns to scale of operations. Technical efficiency results suggest that at the time of the survey, it was more beneficial to drive the efficiency improvements through the employment of "best practice" technology than trying to exploit the scale of operations. Because the size of operations considered by government programs, further analysis examines the size of the operations-productivity relation in detail in the following subsection.

The consistency of the DEA results with respect to specification of the inputoutput relation is evaluated by comparing efficiency rankings. To compare SFA and DEA results, a DEA efficiency ranking is constructed using the average efficiency score computed over the considered growing periods. Table 4 reports rank correlation coefficients for models with a time varying production frontier that ranges from 0.7377 to 0.9726 . Also, high values of ranking correlation coefficients $(0.6555-$ 
0.9362) under the assumption of a common frontier for all periods reported in Table 5 support the hypothesis of robust input-output specifications. The box plots in Figure 3 show the development of technical and pure technical efficiency over the observed growing periods. These box plots reveals that there was no significant technological change over the observed periods. This result is also supported by an analysis of the Malmquist productivity index of technological change, where the index of geometric average technology change is 0.978 and the average index of efficiency change is 1.007 (the unity value of index means no change). Further, the DEA rankings are compared with the SFA rankings estimated by Druska and Horrace (2004). According to the literature on parametric and non-parametric methods comparison, e.g., Wadud and White (2000), a high level of DEA-SFA ranking consistency is observed. Because in each case the majority of the farms are scale inefficient and operating in the decreasing returns to scale region, the following analysis is focused on the efficiency scores obtained from two-output models under variable returns to scale.

\subsection{Factors associated with efficiency}

Using the efficiency scores from the model with a time varying production frontier and assessing characteristics of inefficient and efficient farms summarized in Table 6 , it seems that larger farm size, lower usage of fertilizers and higher pesticides costs tend to be associated with the technical efficiency of farms. To provide a closer look at shifts in distribution of efficiency, box-plots in Figure 4 illustrate the relation of mean values of efficiency scores (under the assumption of the CRS and VRS technology) according to categories of ownership, variety type and BIMAS participation. Even partial application of high yielding varieties shifts farms towards higher efficiency. Mixing types of land status is reflected in a shift towards less efficiency. This may reflect frictions originating from heterogenous ownership 
structures of the land. An striking distributional shift occurs when participation in an intensification program with efficiency is considered. The downward shift may be attributed to the fact that farmers were receiving the same package of inputs that were not efficient production mixes for all of them due to the heterogeneity of conditions. Also, participating farmers, due to easy availability of inputs (e.g., cheap pesticides), may tend to overuse these inputs.

For a more detailed analysis of factors related to technical efficiency, a Tobit model is used. To do this the efficiency is tracked over time under a time variant and invariant production possibility frontier. In the case of the time varying frontier, the efficiency of a farm may not be directly compared with the efficiency of another farm in different time (including itself) because the farm is in each period compared to different "best practice" farms. However, this analysis is beneficial for assessing relative performance improvements. When a pooled production frontier is used, the efficiency of a farm may be directly compared and tracked over time because the production possibility frontier is constructed by use of the same best performers in all periods. Using this approach, the downward efficiency shift is observed in the case when all DMUs in some period faced an unfavorable production condition, e.g., the third and fourth period in Figure 3. To control for these unfavorable conditions, time dummies (t3, t4) are introduced.

In the recent literature on agricultural development (Pearson et al. 1991; Towsend, Kirsten, and Vink 1998; Llewelyn and Williams 1996; Davidova and Latruffe 2003; and Helfand and Levine 2004), the most common variables used to assess the factors associated with farms' efficiency cover characteristics like farm size, age of farmers, schooling of the farmers and employment level of machinery. The Tobit regression defined by equation 4 is estimated for all combinations of frontier types and corrections of efficiency scores (censoring bound).

In this study, the analyzed factors can be divided into three groups: farm specific 
variables (intensity of inputs - labor, fertilizers, seeds and farm size; organizational structure - land status, BIMAS participation, rice variety used), economic factors (prices of some inputs) and environmental factors (wet-dry period, village). Due to the assumption of homogeneity of inputs in all six villages (particulary land quality, sea level), village dummies are include into the models to control for differences across villages.

Table 8 reports the results of the Tobit and random-effect Tobit estimations and Table 9 reports the results of the random-effect estimation when Mundlak's (1978) correction is applied. In all estimated models, the only significant effect of geographical location is found for Ciwangi village. This reflects the fact that Ciwangi village is located in the center part of West Java island with an average altitude of 375 meters, while the rest of the villages are located along the coast (10-15 meters above sea level) or in the central area of island (600-1000 meters above sea level). The difference between the DEA approach and the stochastic frontier analysis is illustrated by the low significance of location effect found in the DEA efficiency score, while Druska and Horrace (2004) report that SFA scores show significant spatial effect.

All the coefficients related to the intensity of input use per hectare have the expected sign, and high consumption of input per unit of size may indicate wastage of the considered input. Sizes of the effects indicate possible substitutability between labor and biochemical inputs (fertilizers and seeds) when searching for efficiency improvements as mentioned by Barker, Herdt, and Rose (1985) in the chapter "Trends In Labor Use And Productivity" (pages 123-140). They also mention that experiments on proper timing and placement of fertilizer suggests that fertilizer inputs can be reduced as much as one third without lowering yields.

As it follows from the estimation results, the effect of the wet season is not clear because several opposing effects occur. It would be natural to expect that a 
significant positive effect of the wet season is due to the water demanding nature of rice. The conjecture is that the positive effect of wet weather is ruled out by the fact that most of the areas lack a reliable transportation system (paved roads) during the wet season and farmers are not capable of delivering proper care to paddies. Also, flooding and lodging can affect yields when severe weather occurs, as mentioned by Pearson et al. (1991).

The prevailing positive but not significant effect of a shift towards land tenancy can be explained by Timmer's (1971) reasoning that ownership status might be associated with the extra effort and motivation of tenant farmers who are attempting to save enough capital to buy their own land. However, Pearson et al. (1991) mention that sharecropping contracts were often arranged so that the benefits of higher returns to land go to owners rather than tenants and this discouraged tenants from increasing their productivity. Also, Umetsu, Lekprichkui, and Chakravorty (2003) and Helfand and Levine (2004) identify a similar negative relationship between landlord share and efficiency; therefore, to assess the effect of land ownership on West Java rice farming, more details on contract arrangement are needed. From the view of principal-agent theories, the trade-off between the insurance and incentive aspects in contracts is the most crucial information. And the simple principalagent models illustrate how sharecropping arises when landlords are unsure about the true ability and can not observe the productivity of their tenants, as in Ray (1998).

Further, the estimation results suggest that a significant positive performance gain comes from employing modern high-yielding varieties. This result is also supported by the observed rapid and widespread replacement of traditional seed varieties with short-duration HYVs during the period 1969-1980. The use of HYVs has transformed the nature of wetland rice agriculture in Indonesia from one of low yields, nonuse of purchased inputs, and single annual rice crops to one of high 
yields, high levels of purchased inputs, and multiple rice crops. So, self-sufficiency was attained in the beginning of the 1980s.

As mentioned in the review, the BIMAS program was an important ingredient of rice development policy in the beginning of the 1970s, while its importance declined by the 1980s after most farmers adopted HYVs and were capable of funding inputs from rice profits. The negative effect of BIMAS participation it not so surprising because the intensification programs provided farmers with a technology package that included input recommendations; subsidized credit, fertilizer and pesticides in prescribed composition. ${ }^{5}$ Also, this result supports the hypothesis that in the later period of the intensification program, the positive effects from introducing HYVs reached their limits. Further, because choice of ownership type, HYV employment and program participation is suspected for possible endogeneity, Table 7 reports the results of exogeneity test statistics by Smith and Blundell (1986). In all cases, we accepted exogeneity of explanatory variables.

Assessing the positive coefficients of seed and urea price, it can be concluded that an increase in these factor prices has a significant impact on increasing efficiency, which can support the thesis that the goal of technological improvement is to reduce costly inputs. The negative effect of fertilizer price on farm efficiency (attaining the given yield level) is the result of low fertilizer use. Barker, Herdt, and Rose (1985) document decreasing returns to scale in yield with respect to fertilizer use. Together with the fact that farmers in Indonesia were applying very low levels of fertilizers compared to industrialized countries' farmers (Japan, South Korea), this indicates that the negative effect of reduced fertilizer use prevails over any positive effect originating from more efficient use of fertilizers.

The opposite effect is observed in the case of pesticides costs (thousands of rupiah per hectare) because pesticides are used to prevent losses while the initial

\footnotetext{
${ }^{5}$ For more details on this intensification package contents, see e.g., Pearson et al. 1991; Barker, Herdt, and Rose 1985; and Lokollo 2002.
} 
application of fertilizers always increases crop yield. Also as mentioned in the section on rice farming, low prices of pesticides lead to overuse, which has negative effects on the yield due to environment degradation. Generalizations about the technical efficiency response to the use of pesticide treatment are difficult to make because of the high number of interacting factors (weather, type of pests, variety resistance).

Farm size in Indonesia has been assessed since the 1960s (Basic Agrarian Law). Since this law was imposed, the average farm size has tended to increase. Farm size is an important production factor because it affects the way of farming. Farm size in Java was much smaller (on average 0.439 hectare in the analyzed sample) than on the outer islands. Pakpahan (1992) reports, using the Agricultural census that the average size of land holding was 1.77 ha in 1973 and 1.78 ha in 1983. This difference provides rationale for the limits imposed by Basic Agrarian Law, which sets the minimum and maximum size of 2 and 20 ha, respectively.

Because of the focus on the relation of farm size to efficiency, the quadratic term was added, as in Wadud and White (2000), to capture non-linearities that were usually not explored in works that identified a negative relationship between farm size and productivity. The negative effect of size on productivity is consistent with the fact that land is considered as an input, and with empirical findings for Asian countries summarized by Ray (1998). Assessing the positive sign for the quadratic term $\left(\right.$ Size $\left.^{2}\right)$, it can be concluded that there exists a threshold size and farms larger than this threshold show a positive relationship between farm size and productivity. These thresholds are calculated using calculus and for a time varying frontier range 1.26-1.44 ha, 1.71-1.88 ha when Mundlak's correction is used, and the average threshold size is 1.60 ha. For the time invariant frontier, the average threshold size is 1.67 ha, while thresholds range from 1.45 to 1.62 ha and $1.68-1.94$ ha for estimations with Mundlak's correction. The computed threshold sizes are 
very similar to the size of rice farms in other parts of Indonesia (outer islands) or East Asia and this result can be used to advocate the intensification programs and legal restrictions with aims to increase the size of rice farms.

Further, these results coincide with Wadud and White's (2000) findings that, on average, farmers with lower land fragmentation (greater plot size) more likely have the opportunity to apply new technologies such as tractors or irrigation, resulting in the higher efficiency of their farms. Also, Pearson et al. (1991) and Ray (1998) note that especially the small size of plots and the impracticality of using tractors in hilly areas are the main constraints on mechanization of land preparation. Under the objective of increasing farm size even pooling of smaller farms may be beneficial because with an increase in farm size, employment of mechanization will allow an increased production of rice and small landowners would lend their plots to larger landowners because the returns from land renting will increase. However, constraints on greater tractor use (especially, on the outer islands) are probably more varied due to topographic limitations and greater difficulty in obtaining and servicing tractors.

Analyzing the time evolution of efficiency scores summarized in Table 8, the sign of the estimated coefficient indicates that the relative technical efficiency was only slightly increasing during the end of the 1970s-beginning of the 1980s. When the time evolution of efficiency scores under a time-varying frontier is considered, this observation indicates that the adoption of efficient techniques is not the major factor for the increase in farms' efficiency, and it supports the view that the increase in rice production was driven by the expansion of the cultivated area. Assessing these results, it is observed that there exist periods where a significant decrease in efficiency is observed, which suggests that positive productivity effects of the green revolution were not fully realized until some years after the initial increase in productivity. These results are consistent with other studies of technological 
change in less developed countries that indicated declining agricultural productivity. For example, Fulginiti and Perrin (1997) confirmed findings that, on average, agricultural productivity has declined in these countries, especially during 19611973, but also during 1974-1985. His findings reveal that declining productivity during the 1974-1985 period characterized even those countries such as Pakistan and the Philippines, where green-revolution varieties of wheat and rice had been widely adopted since the 1960s.

Finally, the estimation results reveal a consistently significant positive relationship between the share of family labor and efficiency measure in all estimated models. As found by Dhungana, Nuthall, and Nartea (2004), this tends to negate the belief that farmers in developing countries are operating inefficiently due to excessive use of family labor. As it was mentioned in the data description section, the timing for delivering proper care to rice plants is crucial. Therefore, the positive relation between share of family labor and efficiency may be explained as the result of seasonal labor scarcity when farmers with larger families are able to deliver their family labor at the time when the demand for labor culminates.

Ray (1998) argues that in a world with unemployment that for somebody who hires labor the opportunity costs of an additional unit of labor are still at the market wage rate, while for family labor the opportunity costs are lower because of the possibility of unemployment. He argues that this leads to higher employment of family labor by farmers with small sized plots. Therefore, the observed positive relation of share of family labor to efficiency is not surprising, and due to the substitutability of inputs the small size farmers deliver more care to the plants and are able to increase the efficiency of other production factors without increasing the use of these factors. 


\section{Conclusion}

This work analyzes the performance of West Java rice farms during the late periods (end of the 1970s-beginning of the 1980s) of the intensification program known as BIMAS. The applied non-parametric approach is more suitable to analyzing production processes in developing countries where the availability of data is limited and production technologies are less understood. The analysis of technical efficiency scores reveals that farmers could benefit from the adoption of the best practice methods of production because the results indicate a wide range of differences in efficiency across farms. On average, the analyzed farms were relatively inefficient with a potential for reducing their inputs from 23 to $42 \%$ to grow the same amount of rice. Decomposing the technical efficiency into pure technical efficiency and scale efficiency, it can be concluded that the majority of farms operate at or close to full scale efficiency. So, farmers that are operating technically inefficiently are doing so because they employ technically inefficient production mixes rather than because of the size of their operations. Further, up to $77 \%$ of scale inefficient farms show decreasing returns to scale.

The second stage analysis of the factors associated with the observed technical efficiency score indicates what aspects of the considered rice farms could be targeted in order to improve efficiency. The employment of modern varieties had a positive and significant effect on the rice farms' performance but the time pattern of productivity suggests that during the considered period the yield potential of already introduced modern varieties was exhausted.

A surprising result is that participation in the intensification program did not provided significantly positive effects on employment of the best practice farming technologies. Similarly as in Daryanto, Battese, and Fleming (2002), the predominance of negative relationships between technical efficiency and participation in the intensification program suggest that the program has often failed to increase the 
technical efficiency of rice farms in West Java. The main assumption of the intensification program (BIMAS) approach was that small scale farmer productivity could be raised if they had better access to certain inputs and used them according to a set of prescribed instructions, but the factors which affects the decision to employ inputs differs significantly among farmers. To be successful, future intensification programs should recognize these differences and be personalized to accommodate them. For personalization, detailed data on farmers' characteristics (education, age and family size of farmers); infrastructure of villages (irrigation, types of roads); and mechanization used (water pumps, tractors or buffalos) should be analyzed for their effects on technical efficiency.

The main result of the size-efficiency relation analysis suggests that it is misleading to generalize the inverse relationship between farm size and productivity as it is noted in recent agricultural studies, e.g., Towsend, Kirsten, and Vink (1998) and Helfand and Levine (2004). The non-linearity in this relation is identified and it allows for the calculation of a threshold size over which the size-efficiency relation turns to be positive. The calculated threshold size coincides with average sizes of rice farms on the other Indonesian islands and in other Asian countries. Assessing this fact, an increase in farm size (pooling plots) looks beneficial for further increasing the production of rice. Also, when the plot sizes will be increased, the production of rice can be mechanized, and this can induce further growth in rice production. When increasing farm size is considered, policy makers should be aware of decreasing returns to scale because for the majority of the West Java farms, an increase in farm size without change in the relative input levels will lead to a decrease in technical efficiency. Therefore, the assessment of increased yields to attain self-sufficiency in rice production should distinguish between enlarging farm size and the efforts to increase technical efficiency of small size farms.

A suggestion that can be drawn from the presented analysis is that the future 
intensification programs have to take into account the capacity of farmers to apply the available technology more efficiently. Therefore, policies aimed at adopting of "best practice" technology should come in the form of personalized intensification programs together with increasing the educational levels of farmers, as many studies on farming performance suggest, e.g., Dawson and Lingard (1991), Llewelyn and Williams (1996), and Dhungana, Nuthall, and Nartea (2004).

\section{References}

Banker, R. D., Abraham Charnes, and William W. Cooper. 1984. "Some Models for Estimating Technical and Scale Inefficiencies in Data Envelopment Analysis." Management Science 30:1078-1092.

Barker, Randolf, Robert W. Herdt, and Beth Rose. 1985. The Rice Economy of Asia. 1616 P S treet, N.W., Washignton D.C., USA: Resources for the Future.

Barrett, C. B. 1996. "On Price Risk and the Inverse Farm Size-Productivity Relationship." Journal of Development Economics 51 (2): 193-216.

Binswanger, Hans P., Klaus Deininger, and Gershon Feder. 1995. Chapter Power, Distortions, Revolt and Reform in Agricultural Land Relations of Handbook of Developmnet Economics, edited by Jere Behrman and T.N. Srinivasan, Volume 3B, 2659-2773. Amsterdam, The Nederlands: Elsevier Science B.V.

Brázdik, František. 2005, August. "Oriented Stochastic Data Envelopment Models: Ranking Comparison With Stochastic Frontier Approach." Working paper 171, CERGE-EI.

Charnes, Abraham, William W. Cooper, Arie Y. Lewin, and Lawrence M. Seiford. 1994. Data Envelopment Analysis: Theory, Methodology and Applications. Kluwer Academic Publishers.

Charnes, Abraham, William W. Cooper, and E. Rhodes. 1978. "Measuring the Efficiency of Decision Making Units." European Journal of Operational Research 2:429-444.

Cooper, W. W. 1999. "Operational Research/Management Science: Where It's Been. Where it Should be Going?" The Journal of the Operational Research Society 50 (1): 3-11 (January).

Daryanto, Heny, George E. Battese, and Euan M. Fleming. 2002, July. "Technical Efficiencies of Rice Farmers Under Different Irrigation Systems and Cropping Seasons in West Java." Asia Conference on Efficiency and Productivity Growth, University of New England, Institute of Economics, Academia Sinica,Taipei Taiwan, Republic of China. 
Davidova, Sofia, and Laure Latruffe. 2003. "Technical Efficiency and Farm Financial Management in Countries in Transition." Institut National del recherche Agronomique Working Paper series 03-01 (December): 1-35.

Dawson, P.J., and J. Lingard. 1991. "Approaches to Measuring Technical Efficiency on Philippine Rice Farms." Journal of International Development 19:211-228.

Dhungana, Basanta R., Peter L. Nuthall, and Gilbert V. Nartea. 2004. "Measuring the Economic Inefficiency of Nepalese Rice Farms Using Data Envelopment Analysis." The Australian Journal of Agricultural and Resource Economics 48 (2): 347-369 (June).

Druska, Viliam, and William C. Horrace. 2004. "Generalized Moments Estimation for Spatial Panel Data: Indonesian Rice Farming." American Journal of Agricultural Economics 86 (1): 185-190.

Erwidodo. 1990. "Panel Data Analysis on Farm-Level Efficiency, Input Demand and Output Supply of Rice Farming in West Java Indonesia." Ph.D. dissertation, Department of Agricultural Economics, Michigan State University.

Erwidodo, Tahlim Sudaryanto, and Sjaiful Bahri. 1999. "Crisis-inducted Policy Reforms and Agricultural Liberalization in Indonesia." ACAIR Indonesia research project Working Paper, vol. 99.03 (January). Presented at Annual Australian Agricultural and Resource Conference, Christchurch.

Farrell, M. J. 1957. "The Measurement of Productive Efficiency." Journal of the Royal Statistical Society - Series A (General) 120 (3): 253-290.

Farrell, M. J., and M. Fieldhouse. 1962. "Estimating Efficient Production Functions under Increasing Returns to Scale." Journal of the Royal Statistical Society - Series A (General) 125 (2): 252-267.

Färe, Rolf, and Shawna Grosskopf. 1994. "Estimation of Returns to Scale Using Data Envelopment Analysis: A Comment." European Journal of Operational Research 79 (3): 379-382.

Fredierick, William H., and Robert L. Worden, eds. 1992, November. Indonesia: A Country Study. $5^{\text {th }}$ ed. Area Handbook Series. US Government Printing Office.

Fried, Harold O., C. A. K. Lovell, Shelton S. Schmidt, and Suthathip Yaisawarng. 2002. "Incorporating the Operating Environment Into a Nonparametric Measure of Technical Efficiency." Journal of Productivity Analysis 17:157-174.

Fried, Harold O., Shelton S. Schmidt, and Suthathip Yaisawarng. 1999. "Incorporating the Operating Environment Into a Nonparametric Measure of Technical Efficiency." Journal of Productivity Analysis 12:249-267.

Fulginiti, Lilyan E., and Richard K. Perrin. 1997. "LDC agriculture: Nonparametric Malmquist Productivity Indexes." Journal of Development Economics 53 (2): 373-390 (August). 
Gallagher, Kevin D. n.d. "Stopping subsisdies for pesticides in Indonesian rice production." Sustainable Development International. Food and Agriculture Organization, Rome, Italy, 71-74.

Greene, William. 2004. "The Behaviour of the Maximum Likelihood Estimator of Limited Dependent Variable Models in the Presence of Fixed Effects." The Econometrics Journal 7 (1): 98-119 (June).

Grigorian, David A., and Vlad Manole. 2002, June. "Determinants of Commercial Bank Performance in Transition: An Application of Data Envelopment Analysis." Technical Report 2850, The World Bank. available at http://ideas.repec.org/p/wbk/wbrwps/2850.html.

Hallam, David, and Fernando Machado. 1996. "Efficiency Analysis with Panel Data: A Study of Portuguese Dairy Farms." European Review of Agricultural Economics 23 (1): 79-93. available at http://ideas.repec.org/a/oup/erevae/v23y1996i1p79-93.html.

Hanoch, Giora, and Michael Rothschild. 1972. "Testing the Assumptions of Production Theory: A Nonparametric Approach." The Journal of Political Economy 80 (2): 256-275 (March-April).

Helfand, Steven M., and Edward S. Levine. 2004. "Farm Size and the Determinants of Productive Efficiency in the Brazilian Center-West." Agricultural Economics 31 (2-3): 241-249 (December).

Horrace, William C., and Peter Schmidt. 1996. "Confidence Statements for Efficiency Estimates from Stochastic Frontier Models." Journal of Productivity Analysis 7:257-282.

Kmenta, Jan. 1990. Elements of Econometrics. 2nd. New York, NY, USA: Macmillan Publishing Company. page 491.

Krasachat, Wirat. 2004. "Technical Efficiencies of Rice Farms in Thailand: A Non-Parametric Approach." The Journal of American Academy of Business, Cambridge 4, no. 1-2 (March).

Kumar, Subodh, and Robert Russell. 2002. "Technological Change, Technological Catch-up and Capital Deepening: Relative Contribution to Growth and Convergence." The American Economic Review 92 (3): 527-548 (June).

Llewelyn, Richard V., and Jeffery R. Williams. 1996. "Nonparametric Analysis of Technical, Pure Technical and Scale Efficiencies for Food Crop Production in East Java, Indonesia." Agricultural Economics 15:113-126.

Lokollo, Erna Maria. 2002, December. "Adoption and Productivity Impacts of Modern Rice Technology in Indonesia." Workshop on Green Revolution in Asia and its transferability to Africa, Tokyo, Japan, Center for Agro-socioeconomic Research and Development, Agency for Agricultural Research and Development, Ministry of Agriculture Indonesia.

Löthgren, Mickael, and Magnus Tambour. 1996, January. "Alternative Approaches to Estimate Returns to Scale in DEA-Models." Working Paper Series in Eco- 
nomics and Finance 90, Stockholm School of Economics - The Economic Research Institute.

Mundlak, Yair. 1978. "On the Pooling of Time Series and Cross Section Data." Econometrica 46 (1): 69-85 (January).

Pakpahan, Agus. 1992, March. "Increasing The Scale Of Small-Farm Operations: III. Indonesia." Extension bulletins, Center for Agro-Socioeconomic Research, Agency for Agricultural Research and Development, Bogor, Indonesia. http://www.fftc.agnet.org/library/article/eb344c.html.

Parikh, A., F. Ali, and M. K. Shah. 1995. "Measurement of Economic Efficiency in Pakistan Agriculture." American Journal of Agricultural Economics 77:675685.

Pearson, Scott, Walter Falcon, Paul Heytens, Eric Monke, and Rosamund Naylor. 1991. Rice Policy In Indonesia. Ithaca, NY, USA: Cornell University Press.

Ray, Debraj. 1998. Development Economics. Princeton, New Jersey, USA: Princeton University Press.

Sang, Kwon Oh, and Lee Hyunok. 2004. "Productivity Improvement in Korean Rice Farming: Parametric and Non-parametric Analysis." The Australian Journal of Agricultural and Resource Economics 48 (2): 323-346.

Seiford, Lawrence M., and Robert M. Thrall. 1990. "Recent Developments in DEA: The Mathematical Programming Approach to Frontier Analysis." Journal of Econometrics 46:7-38.

Shafiq, Muhammad, and Tahir Rehman. 2000. "The Extent of Resource Use Inefficiencies in Cotton Production in Pakistan's Punjab: An Application of Data Envelopment Analysis." Agricultural Economics 22 (3): 321-330 (April).

Simar, Léopold, and Paul W. Wilson. 2000. "Statistical Inference in Nonparametric Frontier Models: The State of the Art." Journal of Productivity Analysis 13 (1): 49-78 (January).

Smith, Richard J., and Richard W. Blundell. 1986. "An Exogeneity Test for a Simultaneous Equation Tobit Model with an Application to Labor Supply." Econometrica 54 (3): 679-686 (May).

Spearman, C. 1904. "The Proof and Measurement of Association Between Two Things." American Journal of Psychology 15:72-101.

Stata Corporation. 2003. Stata 8.0 Reference Manual: N-Z. Stata Statistical Software Release 8.0. College Station, Texas, USA.

Timmer, C. P. 1971. "Using a Probabilistic Frontier Production Function to Measure Technical Efficiency." The Journal of Political Economy 79 (4): 776794 (July-August).

Tone, Kaoru. 1993. "An Epsilon-Free DEA and a New Measure of Efficiency." Journal of the Operations Research Society of Japan 36 (3): 167-174. 
Towsend, R.F., J. Kirsten, and N. Vink. 1998. "Farm size, Productivity and Returns to Scale in Agriculture Revisited: A Case Study of Wine Producers in South Africa." Agricultural Economics 19:175-180.

Umetsu, Chieko, Thamana Lekprichkui, and Ujjayant Chakravorty. 2003. "Efficiency and Technical Change in the Philipine Rice Sector: A Malmquist Total Factor Productivity Analysis." American Journal of Agricultural Economics 85 (4): 943-963 (November).

Wadud, Md Abdul, and Ben White. 2000. "Farm Household Efficiency in Bangladesh: a Comparison of Stochastic Frontier and DEA Methods." $A p$ plied Economics 32 (13): 1665-1673 (October).

Wooldridge, Jeffrey M. 2002. Econometric Analysis of Cross Section and Panel Data. Cambridge, Massachusetts, USA: The MIT Press.

Zhu, Joe, and Zhao-Han Shen. 1995. "Theory and Methodology: A Discussion of Testing DMUs' Returns to Scale." European Journal of Operational Research 81 (3): 590-596.

\section{A Figures and Tables}

\begin{tabular}{l||rcrrrr}
\hline Variables & Farms & Periods & Mean & Std. Dev. & Min & \multicolumn{1}{c}{ Max } \\
\hline \hline Inputs & & & & & & \\
Land (hectares) & 160 & 6 & 0.439 & 0.560 & 0.014 & 5.322 \\
Seed (kg) & 160 & 6 & 18.470 & 46.681 & 1.000 & 1250.000 \\
Urea (kg) & 160 & 6 & 96.525 & 130.393 & 1.000 & 1250.000 \\
Phosphate (kg) & 160 & 6 & 33.807 & 48.348 & 0.000 & 700.000 \\
Labor (hours) & 160 & 6 & 394.224 & 496.016 & 17.000 & 4774.000 \\
Outputs & & & & & & \\
Gross yield (kg) & 160 & 6 & 1414.205 & 1966.252 & 42.000 & 20960.000 \\
Net Yield (kg) & 160 & 6 & 1248.825 & 1675.924 & 42.000 & 17610.000 \\
Harvest costs (kg) & 160 & 6 & 165.380 & 302.433 & 0.000 & 3350.000 \\
\hline
\end{tabular}

Table 1: Input-Output summary 


\begin{tabular}{|c|c|c|c|c|c|c|}
\hline \multicolumn{2}{|l|}{ Model } & Obs. & Mean & Std.Dev. & Min & Max \\
\hline \multirow[t]{5}{*}{ One-output } & $\chi^{\prime-\mathrm{CCR}}$ & 960 & (0.6016 & 0.2158 & (0.1869 & 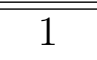 \\
\hline & $\theta-\mathrm{CCR}$ & 960 & 0.6750 & 0.1956 & 0.2553 & 1 \\
\hline & $\chi-\mathrm{BCC}$ & 960 & 0.6777 & 0.2149 & 0.2056 & 1 \\
\hline & $\theta-\mathrm{BCC}$ & 960 & 0.7457 & 0.1922 & 0.3227 & 1 \\
\hline & Scale efficiency & 960 & 0.9074 & 0.1190 & 0.4029 & 1 \\
\hline \multicolumn{7}{|l|}{ Two-outputs } \\
\hline & $\chi^{-\mathrm{CCR}}$ & 960 & 0.6199 & 0.2221 & 0.1612 & 1 \\
\hline & $\theta-\mathrm{CCR}$ & 960 & 0.7069 & 0.1942 & 0.2795 & 1 \\
\hline & $\chi-\mathrm{BCC}$ & 960 & 0.7016 & 0.2216 & 0.2065 & 1 \\
\hline & $\theta-\mathrm{BCC}$ & 960 & 0.7757 & 0.1884 & 0.3294 & 1 \\
\hline & Scale efficiency & 960 & 0.9126 & 0.1123 & 0.4493 & 1 \\
\hline \multicolumn{7}{|c|}{ Two-outputs - pooled frontier } \\
\hline & $\chi-\mathrm{CCR}$ & 960 & 0.5155 & 0.2024 & 0.1647 & 1 \\
\hline & $\theta-\mathrm{CCR}$ & 960 & 0.5866 & 0.1948 & 0.2116 & 1 \\
\hline & $\chi^{-\mathrm{BCC}}$ & 960 & 0.5913 & 0.2012 & 0.2309 & 1 \\
\hline & $\theta-\mathrm{BCC}$ & 960 & 0.6533 & 0.1988 & 0.2591 & 1 \\
\hline & Scale efficiency & 960 & 0.9003 & 0.1183 & 0.3618 & 1 \\
\hline
\end{tabular}

Table 2: Efficiency scores $(\chi)$ and technical efficiency $(\theta)$ summary statistics

\section{Per period frontier}
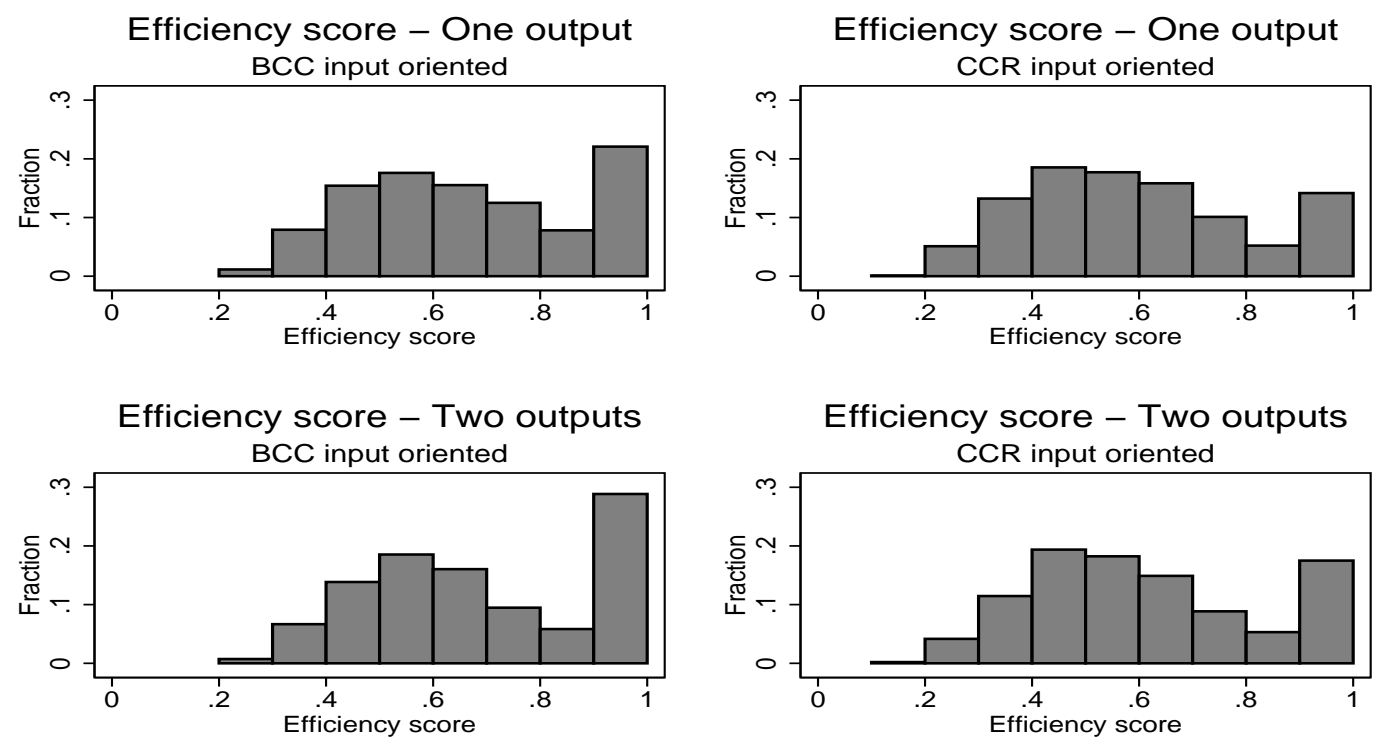

Figure 1: Histograms of efficiency scores $\left(\chi_{j}\right)$ 


\section{Common frontier}
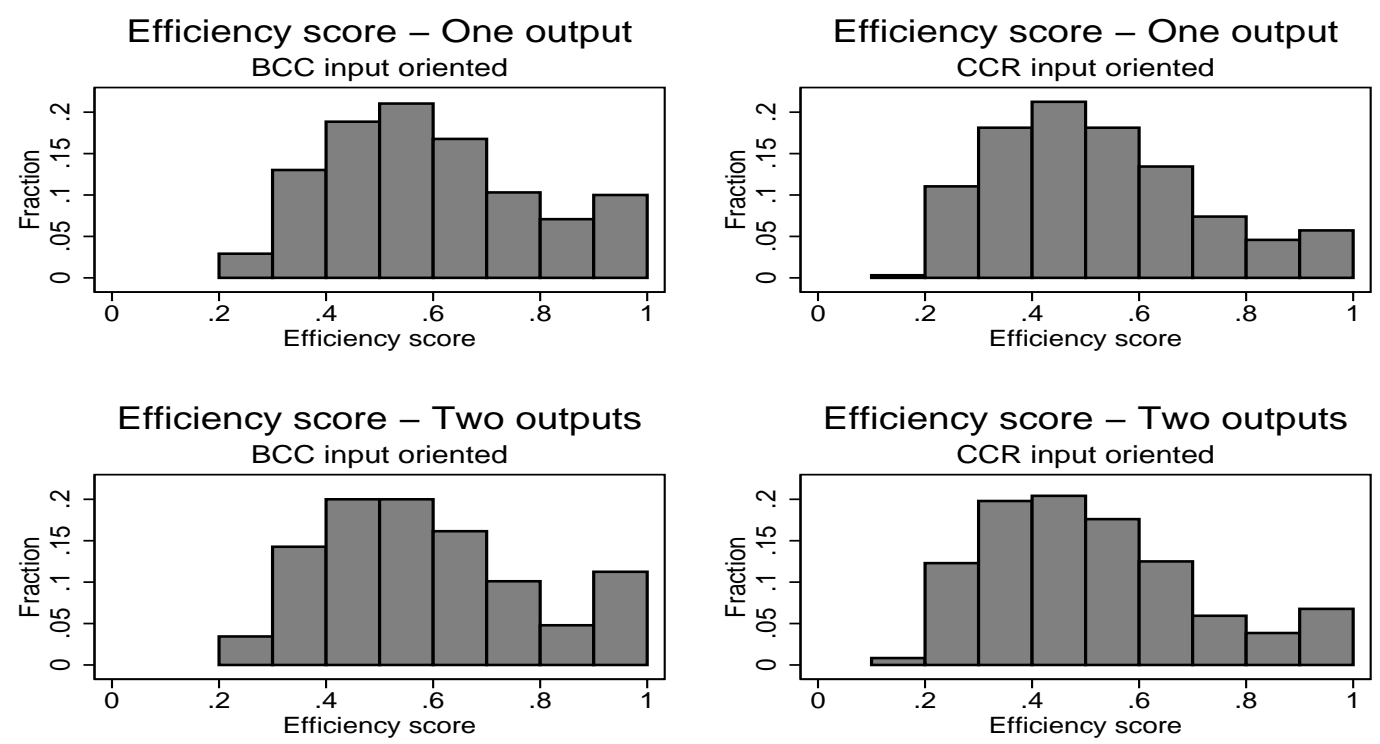

Figure 2: Histograms of efficiency scores $\left(\chi_{j}\right)$ for pooled sample
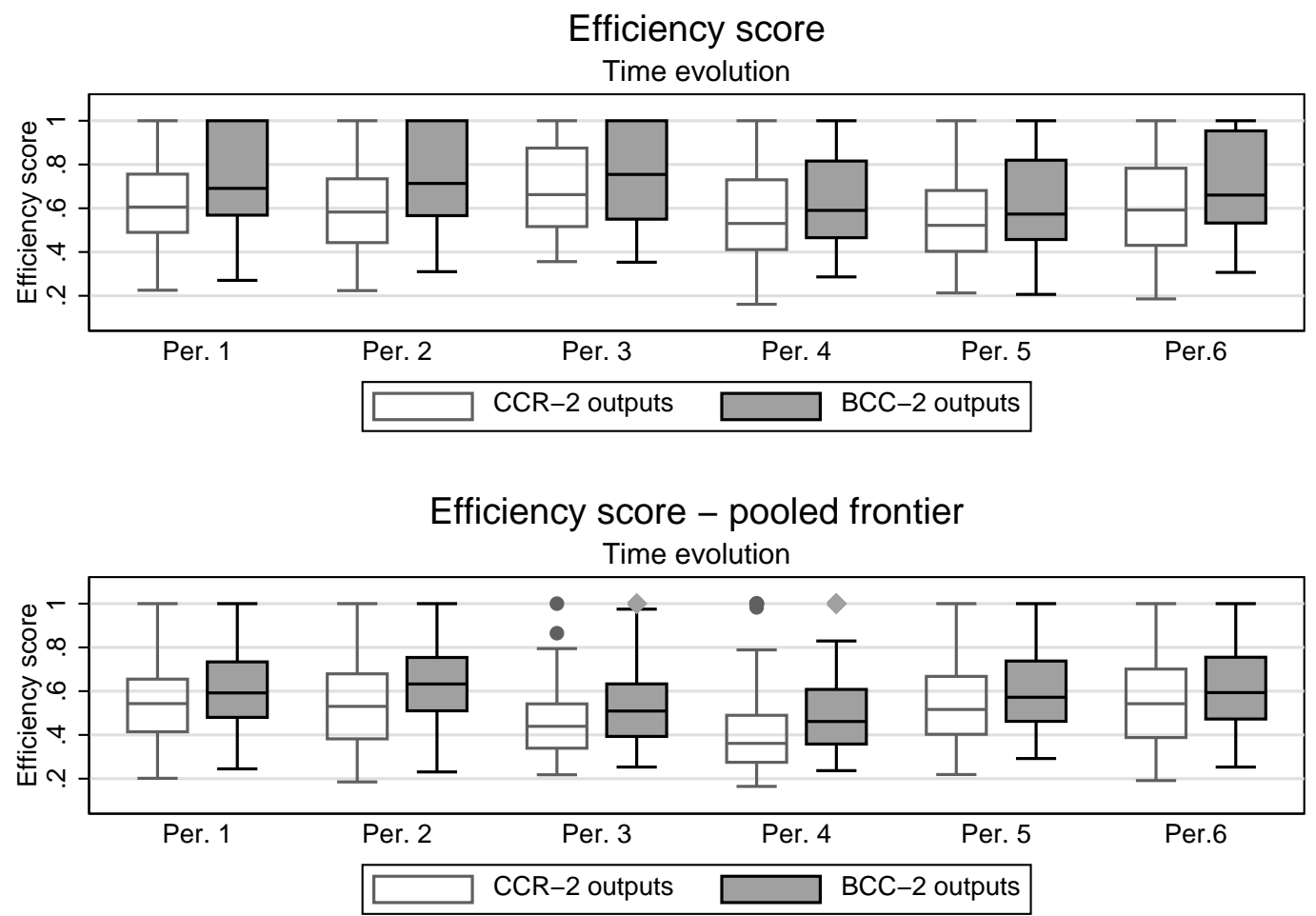

Figure 3: Mean efficiency score over time 


\begin{tabular}{l||ccc}
\hline \hline Model & DRS & CRS & IRS \\
\hline One-output & $66 \%$ & $12 \%$ & $22 \%$ \\
Two-outputs & $62 \%$ & $16 \%$ & $22 \%$ \\
Two-outputs - pooled frontier & $77 \%$ & $5 \%$ & $18 \%$ \\
Thailand* $_{\text {Bangladesh** }}^{*}$ & $19 \%$ & $32 \%$ & $49 \%$ \\
\hline
\end{tabular}

* From Krasachat (2004), ${ }^{* *}$ From Wadud and White (2000)

Table 3: Returns to scale summary

\begin{tabular}{l||lllll}
\hline \multicolumn{1}{l||}{ Rankings } & \multicolumn{3}{c}{ One-output } & \multicolumn{3}{c}{ Two-outputs } & SFA \\
\hline \hline One-output & CCR & BCC & CCR & BCC & \\
CCR & 1.0000 & & & & \\
BCC & 0.7377 & 1.0000 & & & \\
Two-outputs & & & & & \\
CCR & 0.9714 & 0.7318 & 1.0000 & & \\
BCC & 0.7520 & 0.9726 & 0.7632 & 1.0000 & \\
& & & & & \\
SFA & 0.8521 & 0.6080 & 0.8248 & 0.6114 & 1.0000 \\
\hline \multicolumn{4}{l}{ Note: In all cases the hypothesis of rank independence was rejected at the $1 \%$ significance level. }
\end{tabular}

Table 4: Spearman rank correlation coefficients

\begin{tabular}{l||ccccc}
\hline \multicolumn{1}{l||}{ Rankings } & \multicolumn{4}{c}{ Two-outputs } & \multicolumn{2}{l}{ Two-outputs - pooled } & SFA \\
& CCR & BCC & CCR & BCC & \\
\hline \hline Two-outputs & 1.0000 & & & & \\
CCR & 0.7377 & 1.0000 & & & \\
BCC & & & & & \\
Two-outputs - pooled frontier & 0.9342 & 0.6195 & 1.0000 & & \\
CCR & 0.7736 & 0.9235 & 0.7300 & 1.0000 & \\
BCC & & & & & 1.0000 \\
\multicolumn{1}{l|}{ SFA } & 0.8521 & 0.6080 & 0.8248 & 0.6114 & \\
\hline
\end{tabular}

Table 5: Spearman rank correlation coefficients 


\begin{tabular}{l||rrrrr}
\hline \multicolumn{7}{l}{ Inefficient production mixes } \\
\hline Variable & Obs & Mean & Std. Dev. & Min & Max \\
Size & 711 & 0.3977 & 0.4029 & 0.0360 & 3.6430 \\
Land status & 711 & 1.3713 & 0.6097 & 1 & 3 \\
Variety & 711 & 1.5218 & 0.8503 & 1 & 3 \\
BIMAS & 711 & 1.3417 & 0.6301 & 1 & 3 \\
Seed per ha & 711 & 43.5229 & 38.9072 & 13.0841 & 857.1429 \\
Urea per ha & 711 & 237.8890 & 107.3938 & 6.9930 & 712.2507 \\
Phosphate per ha & 711 & 98.1660 & 70.1368 & 0.0000 & 418.9944 \\
Labor per ha & 711 & 1060.4180 & 463.1572 & 314.0625 & 3414.6340 \\
Family labor ratio & 711 & 0.5122 & 0.2701 & 0.0006 & 1.0000 \\
Yield per ha & 711 & 3048.3050 & 1064.2220 & 630.6667 & 6305.7320 \\
Pesticides costs & 711 & 459.2194 & 1755.3570 & 0.0000 & 24000 \\
\hline Efficient production mixes & \multicolumn{3}{c}{} & \\
\hline Variable & Obs & Mean & Std. Dev. & Min & Max \\
Size & 249 & 0.5599 & 0.8551 & 0.0140 & 5.3220 \\
Land status & 249 & 1.3574 & 0.6874 & 1 & 3 \\
Variety & 249 & 1.8313 & 0.9649 & 1 & 3 \\
BIMAS & 249 & 1.2610 & 0.5536 & 1 & 3 \\
Seed per ha & 249 & 43.6059 & 33.9238 & 4 & 350.1401 \\
Urea per ha & 249 & 206.9264 & 131.4522 & 0.8748 & 682.7586 \\
Phosphate per ha & 249 & 70.0780 & 76.5883 & 0.0000 & 375.9398 \\
Labor per ha & 249 & 990.7551 & 516.3687 & 108.0000 & 2966.6670 \\
Family labor ratio & 249 & 0.5854 & 0.3193 & 0.0002 & 1.0000 \\
Yield per ha & 249 & 3884.5560 & 1467.2710 & 400.0000 & 7910.3450 \\
Pesticides costs & 249 & 1017.4500 & 5113.0330 & 0.0000 & 62600 \\
\hline
\end{tabular}

Table 6: Efficient vs. inefficient production mixes

\begin{tabular}{ll||ccc}
\hline Model & variable & Test stat. & P-value & exogeneity \\
\hline \hline Probit & variety & 0.1765 & 0.6744 & accepted \\
& land status & 1.0751 & 0.2998 & accepted \\
& BIMAS & 1.0573 & 0.3038 & accepted \\
Tobit & variety & 1.4556 & 0.2279 & accepted \\
& land status & 0.8322 & 0.3619 & accepted \\
& BIMAS & 2.4549 & 0.1175 & accepted \\
\hline
\end{tabular}

Table 7: Smith-Blundell test of exogeneity for time invariant frontier 


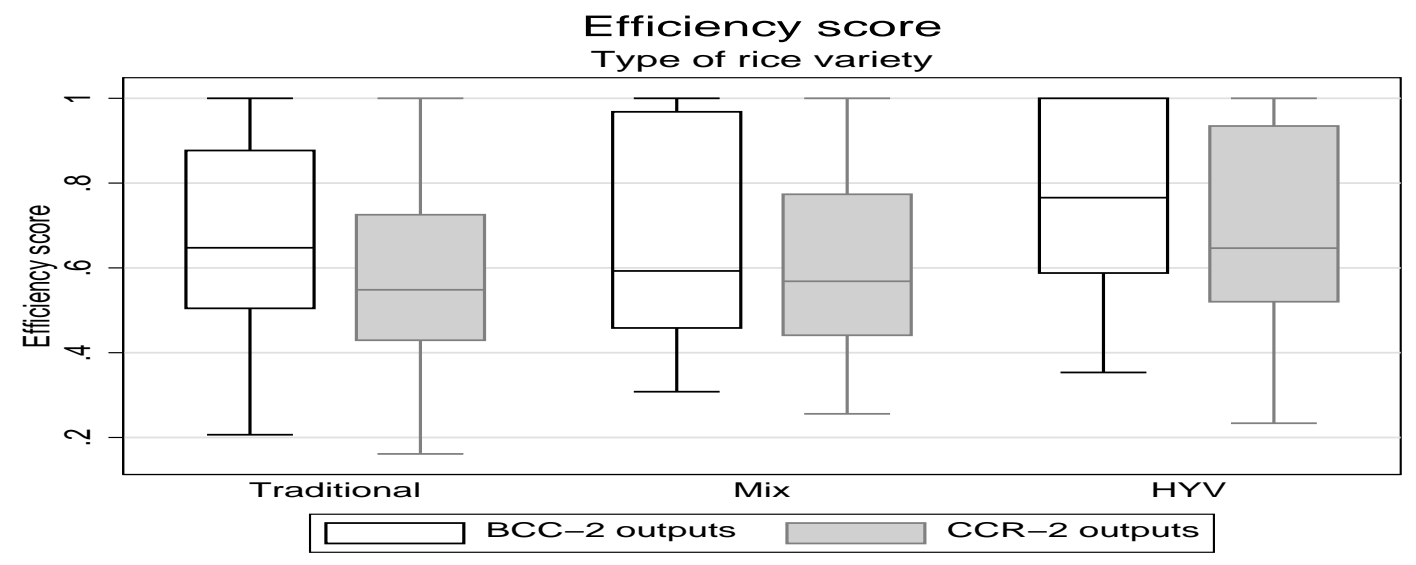

Efficiency score

Type of sharecropping

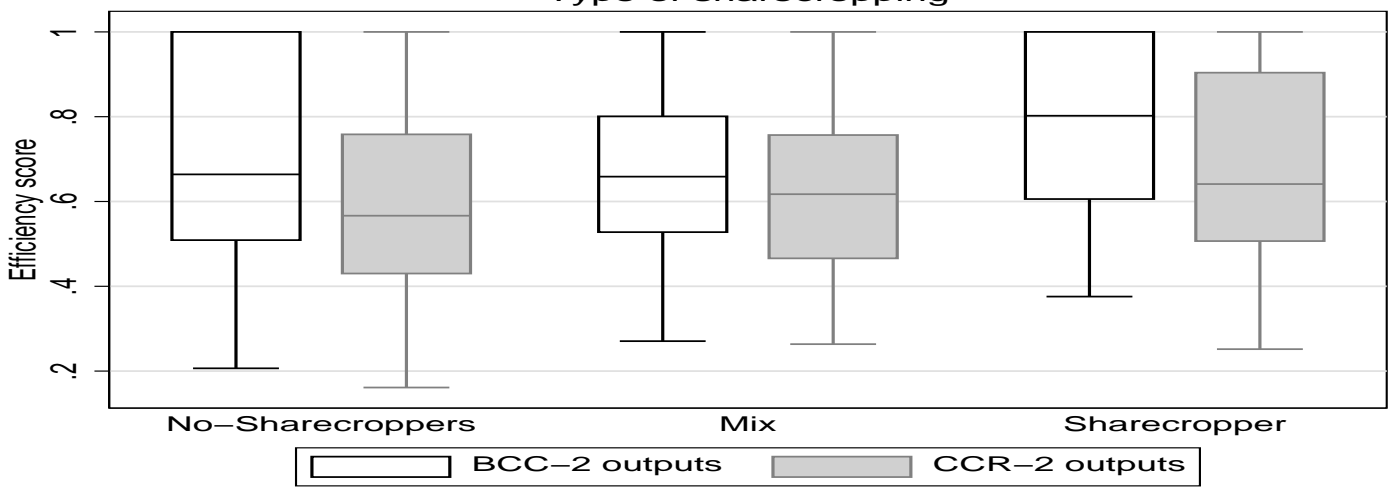

Efficiency score

Type of farm

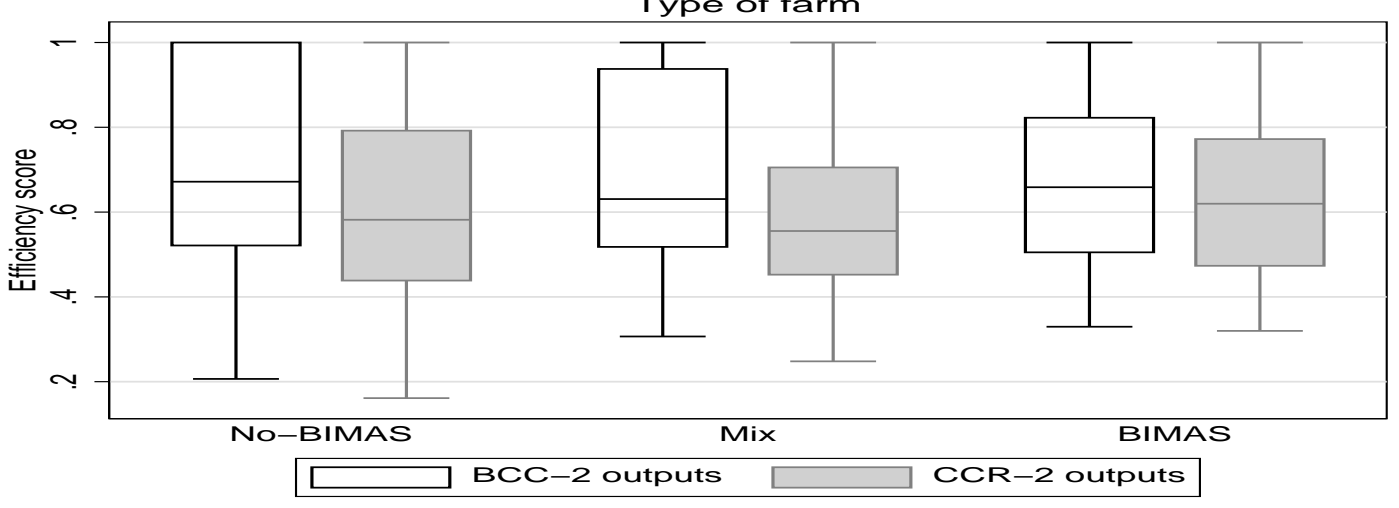

Figure 4: Efficiency scores by farm characteristics 


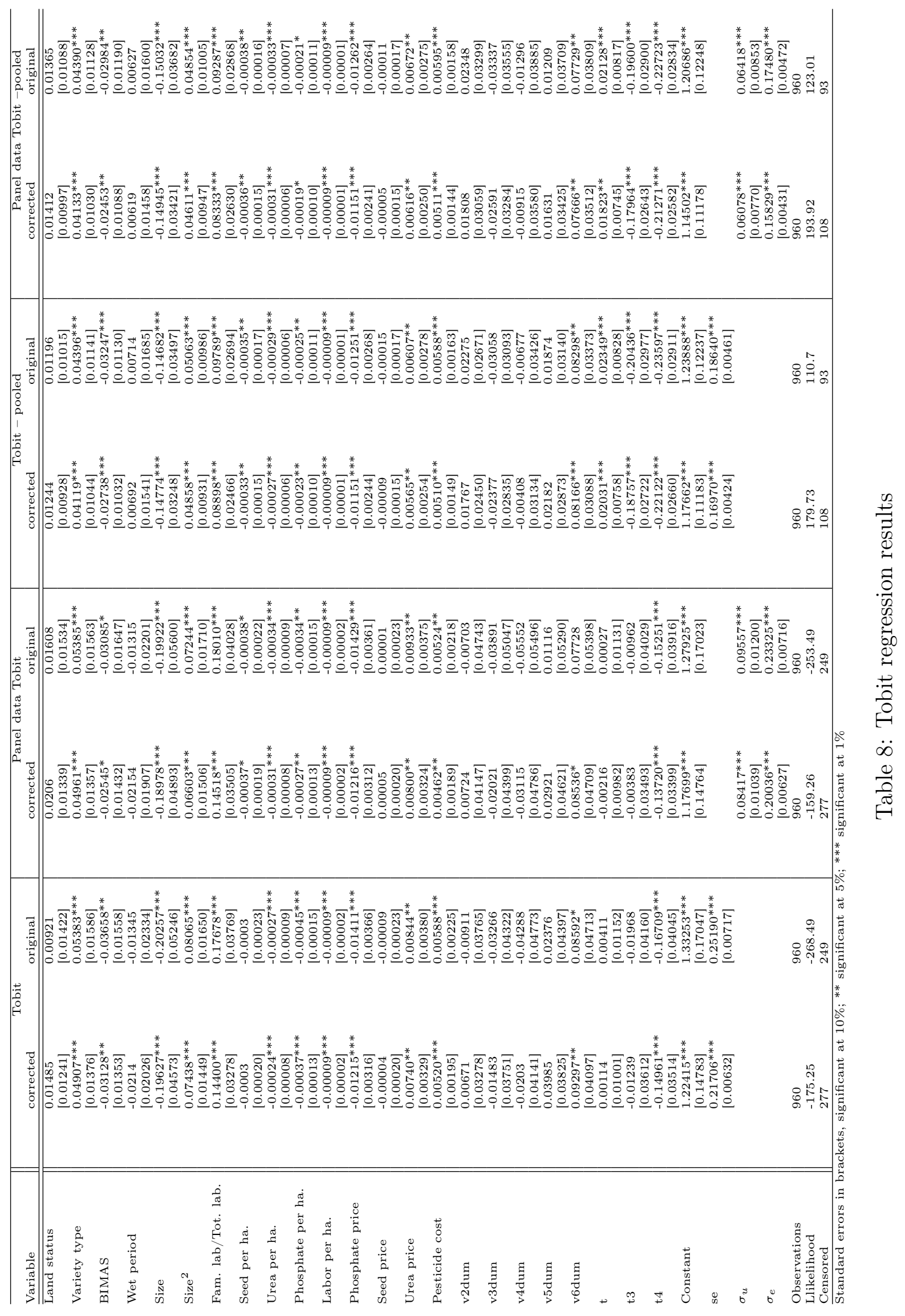




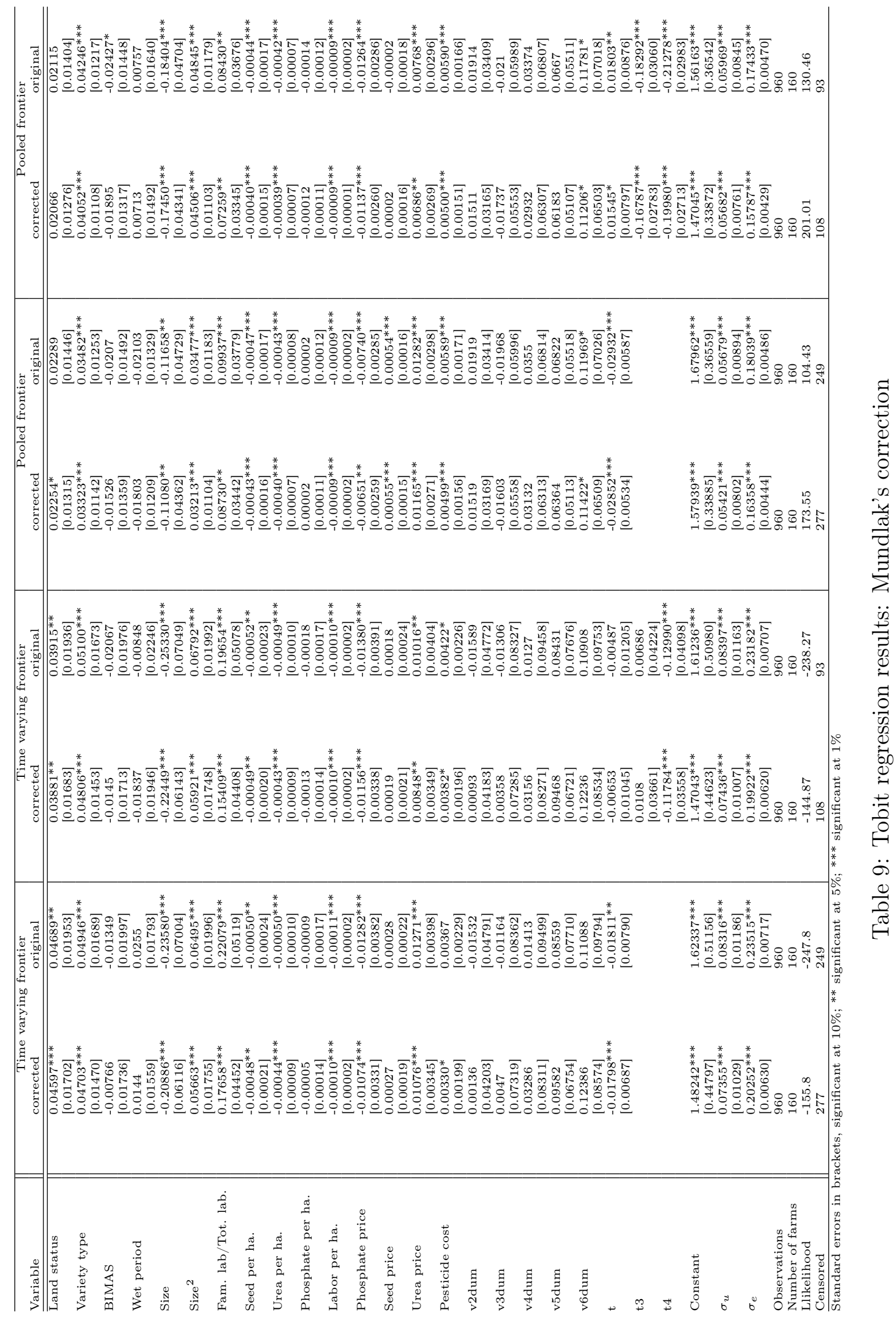


Individual researchers, as well as the on-line and printed versions of the CERGE-EI Working Papers (including their dissemination) were supported from the following institutional grants:

- Center of Advanced Political Economy Research [Centrum pro pokročilá politicko-ekonomická studia], No. LC542, (2005-2009),

- Economic Aspects of EU and EMU Entry [Ekonomické aspekty vstupu do Evropské unie a Evropské měnové unie], No. AVOZ70850503, (2005-2010);

- Economic Impact of European Integration on the Czech Republic [Ekonomické dopady evropské integrace na ČR], No. MSM0021620846, (2005-2011);

Specific research support and/or other grants the researchers/publications benefited from are acknowledged at the beginning of the Paper.

(c) František Brázdik, 2006

All rights reserved. No part of this publication may be reproduced, stored in a retrieval system or transmitted in any form or by any means, electronic, mechanical or photocopying, recording, or otherwise without the prior permission of the publisher.

Published by

Charles University in Prague, Center for Economic Research and Graduate Education (CERGE) and

Economics Institute (EI), Academy of Sciences of the Czech Republic

CERGE-El, Politických vězňu 7, 11121 Prague 1, tel.: +420 224005 153, Czech Republic.

Printed by CERGE-EI, Prague

Subscription: CERGE-El homepage: http://www.cerge-ei.cz

Editors: Directors of CERGE and EI

Managing editors: Deputy Directors for Research of CERGE and EI

ISSN 1211-3298

ISBN 80-7343-081-9 (Univerzita Karlova v Praze, CERGE)

ISBN 80-7344-070-9 (Národohospodářský ústav AV ČR, Praha) 
CERGE-EI

P.O.BOX 882

Politických vězňů 7

11121 Praha 1

Czech Republic http://www.cerge-ei.cz 